\title{
دلفى ووحيها
}

د. عزيزة حسن السيد سليمان محجوب

مقدمة : مقا:

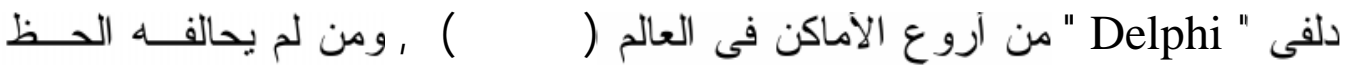

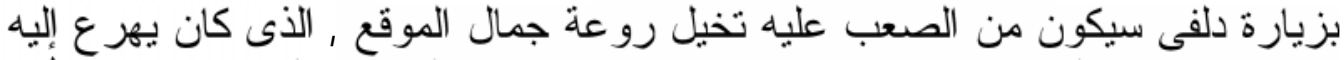

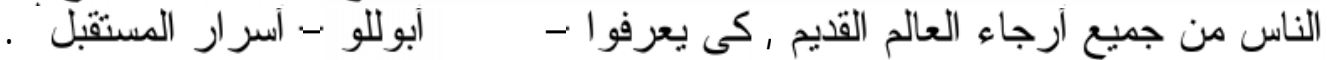

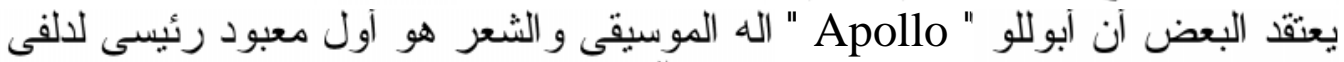

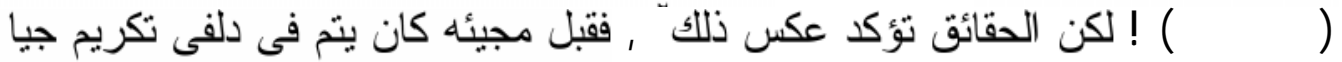

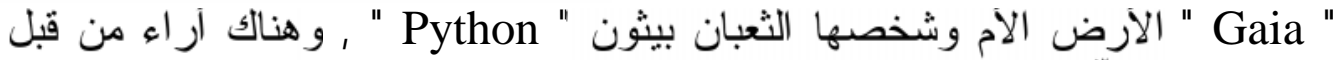
بعض اللغويين" تقول الن كلمة بيثون من الناحية اللغوية كانت تعنى قديماً ( مكان

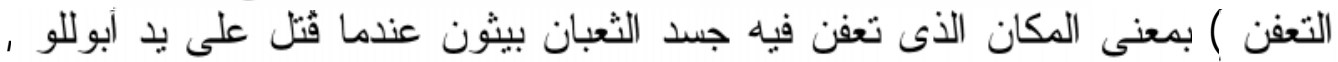

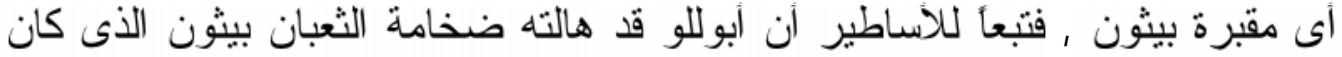

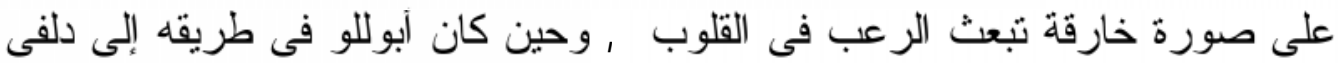

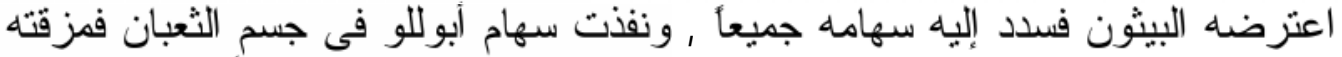

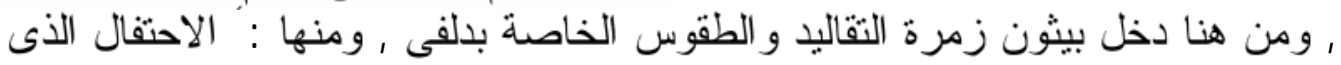

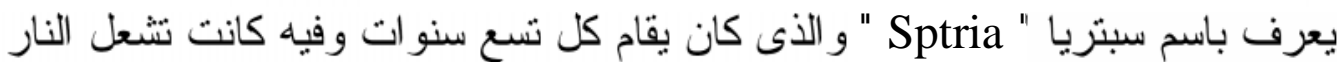

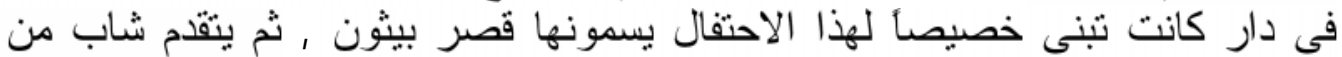

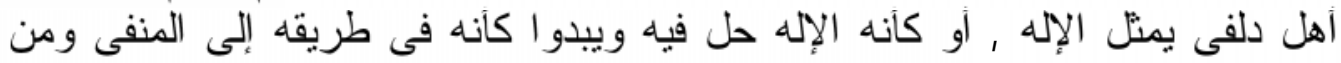

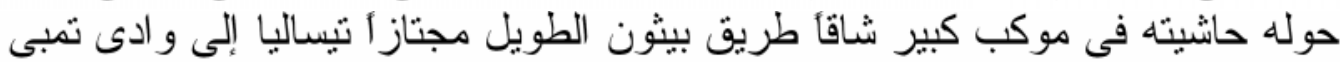

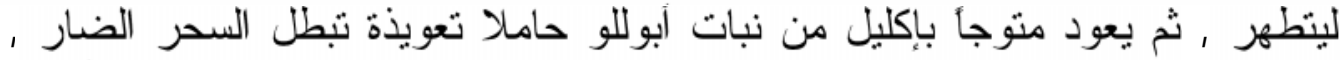

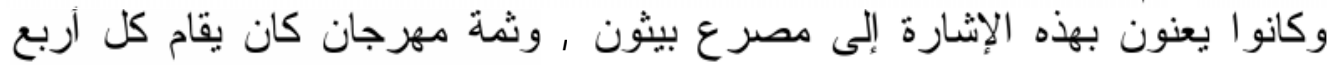

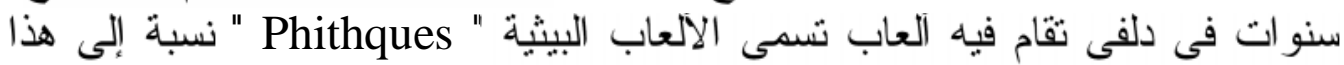
الافعوان بيثون الذى صرعه أبوللو , وفى هذا المهرجان كانت تتظم الّوانا من مسابقات

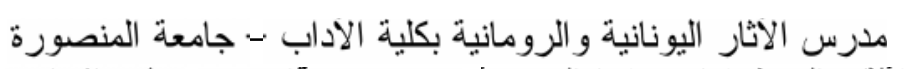

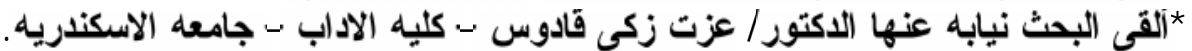

1 - Poulsem, F- , " Delphische Studiem " , ( Copenhague , 1924 )

2 - Williamson, M. , " The Sacret and The Jeminine in Ancient Greece " , ( London and New York, 1998 ) P. 7

3 - Pomtow , H. article Delphoi dans la Real - Encyclopadie der classischen Altertums wissenschaft " , t. IV et suppl . IV

ع - ثروت عكاشة ' الاغريق بين الاسطورة و الابداع ' ( الجزء الخامس عشر - الطبعة الثانية -

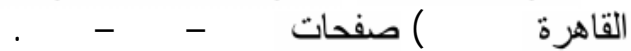


الجرى و المصار عة وسباق المركبات , و اختبار ات موسيقية ومسابقات تمثيلية وكانت

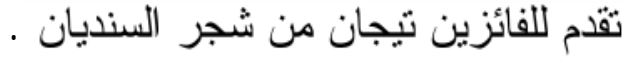
كان بزيد من أهية دلفى أنها كانت إحدى مركزى اجنماع التحالف الامفيكتيون

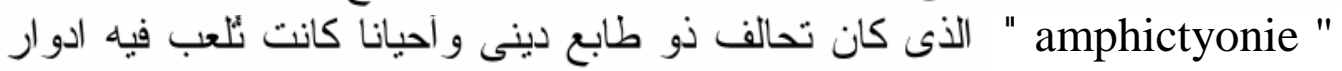

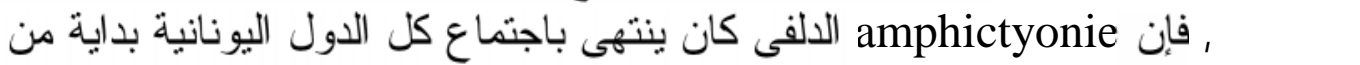

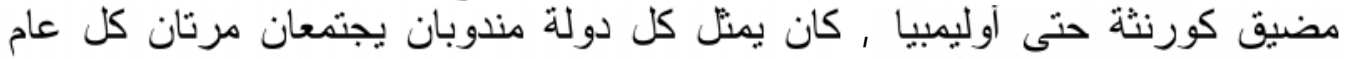

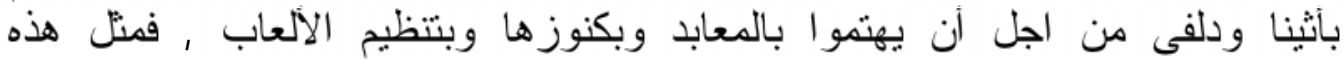

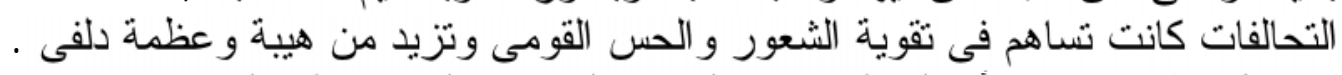

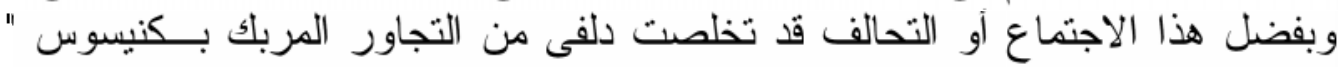
knissa " مقدينة knissa مقامة على الطريق الذى يؤدى إلى ميناء

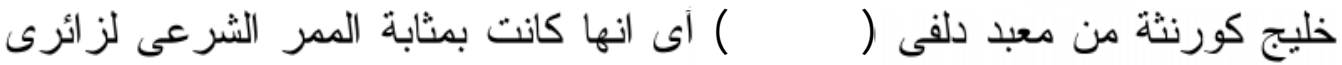

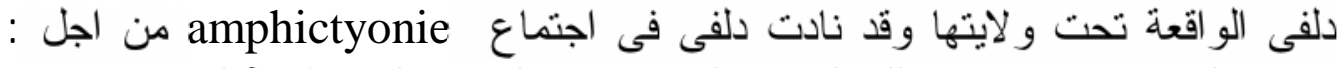

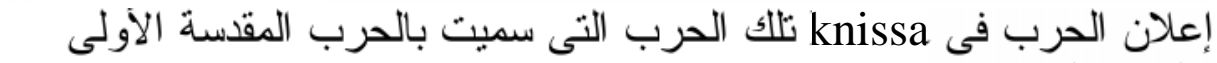

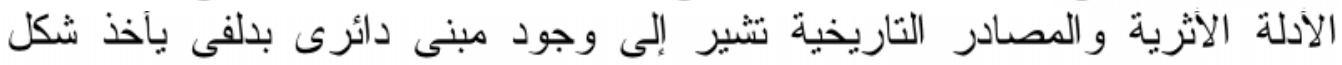

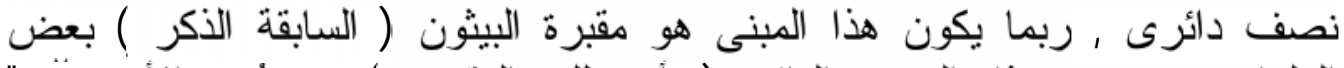

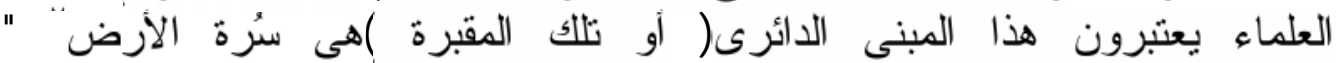

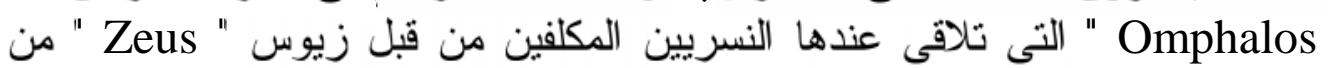

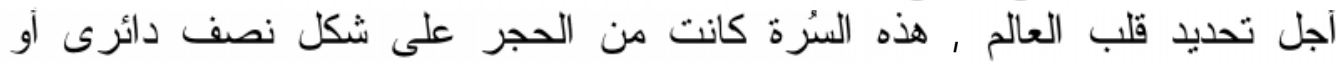

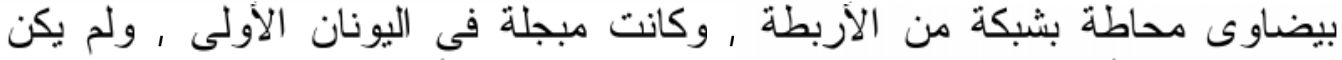

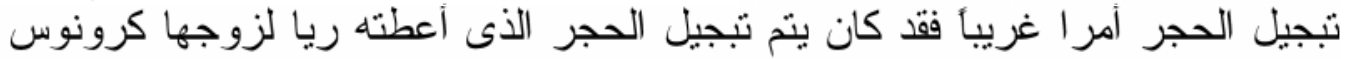

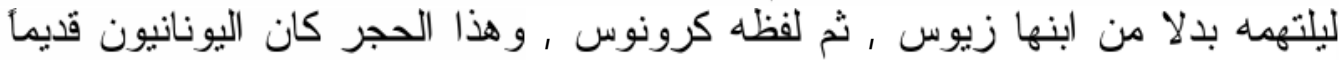

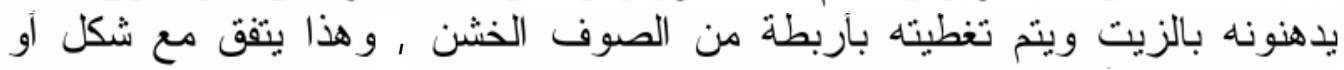

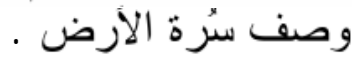

يعتقد بعض العلماء أن هذا المبنى الدائرى أو المقبرة الدائرية خاصة بديونيسوس^ " 'Dionysos

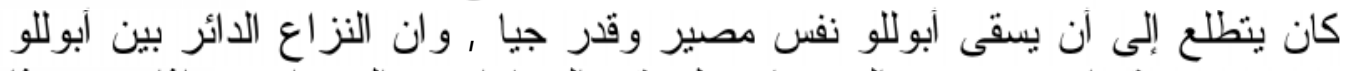

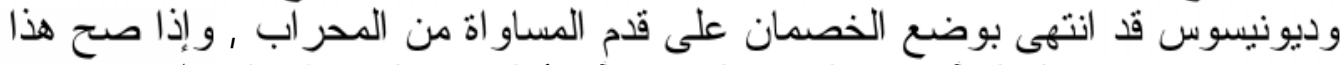

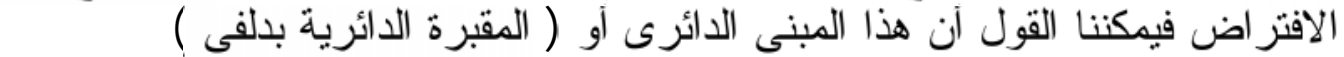

5- Mc Donald,W. A. ,"The Political Meeting places of the Greeks",(Baltimore, 1943 ), P. 73

6 - Widal - Naquet P., " The Black Hunter forms of Thonght and forms of society in the ancient world " , ( London , 2000 ), , P. 60

7 - Dörpfeld ,W. , " Alt - Olympia " , ( Text and Tafelm ), ( Berlim, 1935 ) P. 42

8 - Poulsem, F. , " Delphi " , ( Londres , 1920 ) , P. ZI 
الغرفة المقببة المحددة من الجانبين بطائرين هما نسور زيوس فى المبانى اليونانية ,

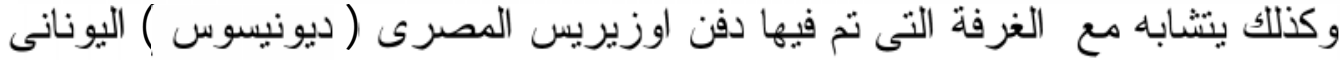

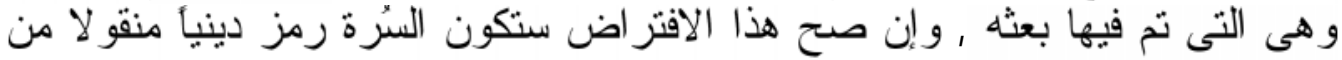

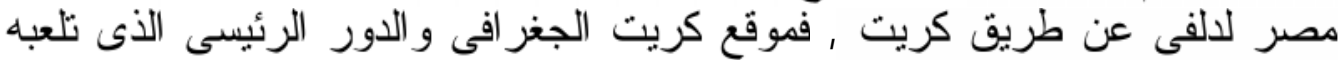

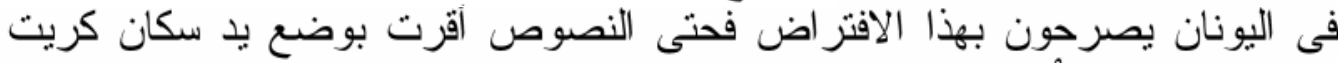

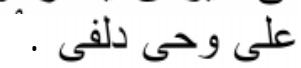

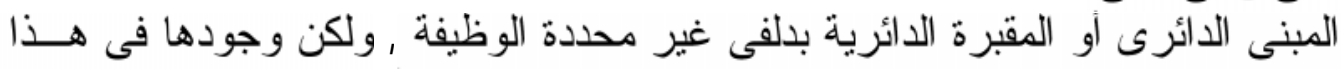

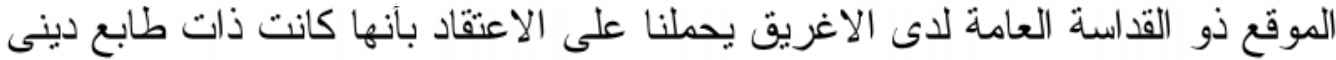

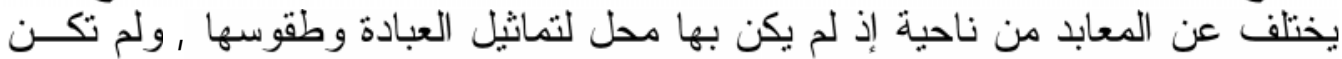

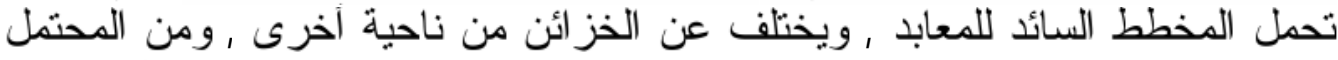

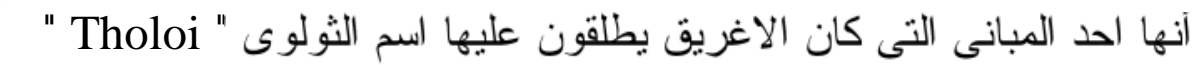

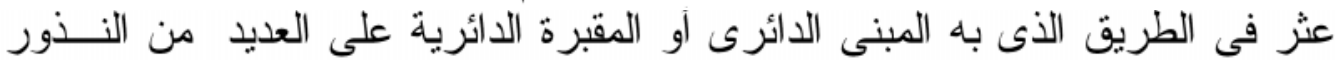

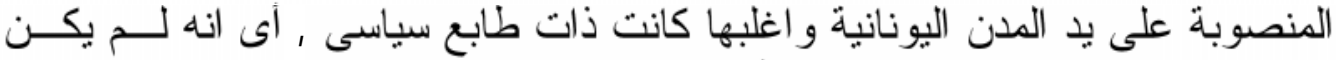

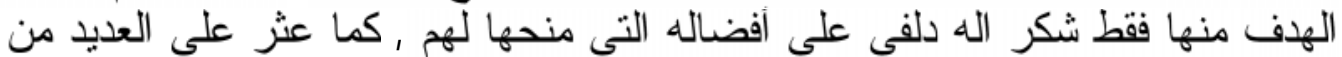

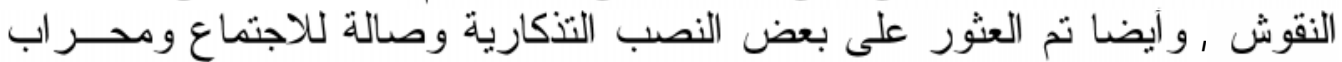

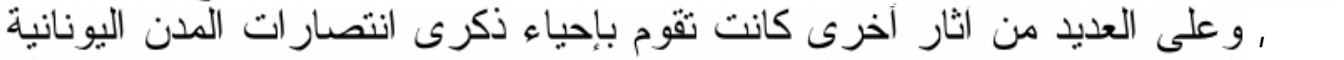

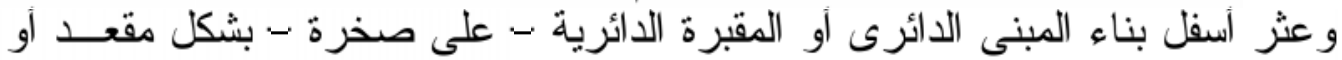

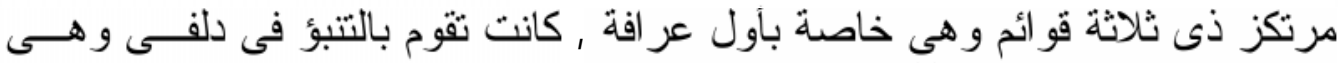

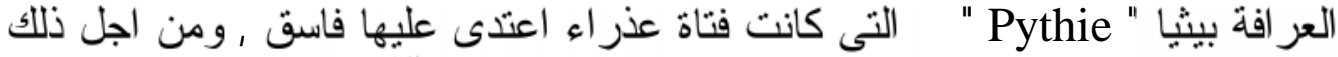

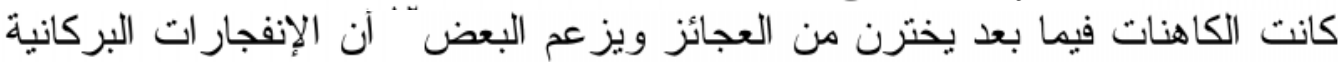

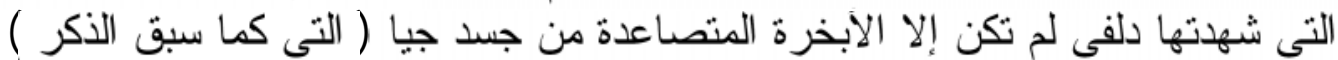

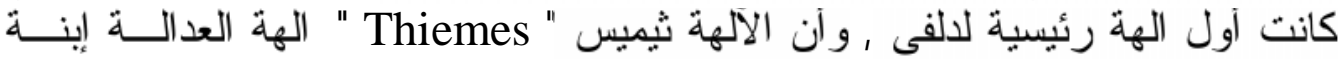

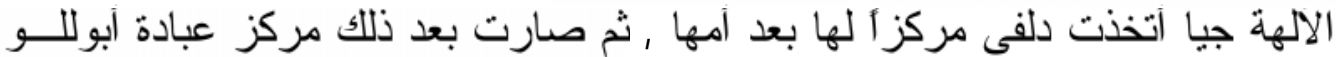

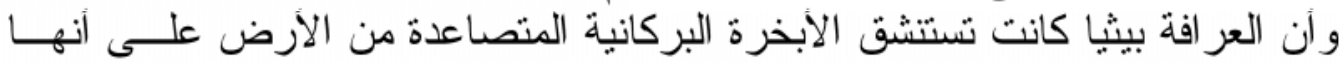

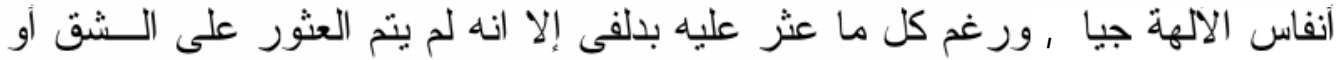

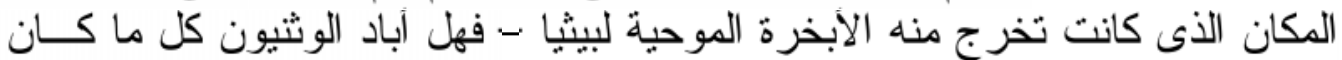
يسمح باختر اق أسر ار الوحى أم هم المسيحيون ؟

$$
9
$$

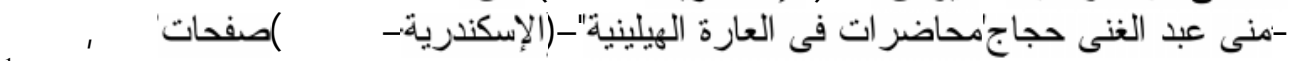

11 - Dillon, M. , " Girls and women in classical Greek Religion " , ( 2 ndedn Routledge )

( London and New York, 2000), P. 77

12 - Dillon, op . cit ., P. 98 
كان ثمة خلط منذ العصور القديمة بين بيثا وكوبيلى الهاتفة الإلهية التى دارت حولهــــا

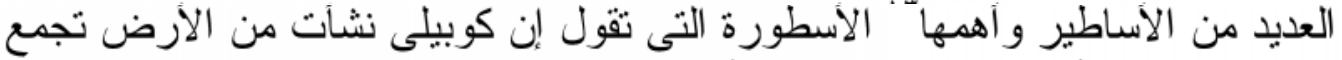

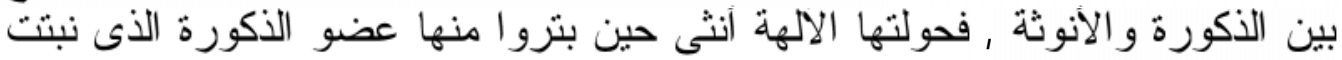

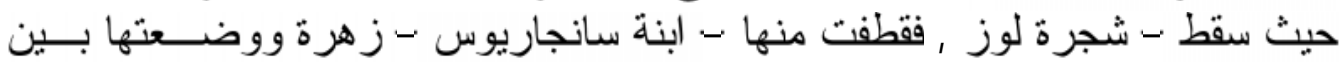

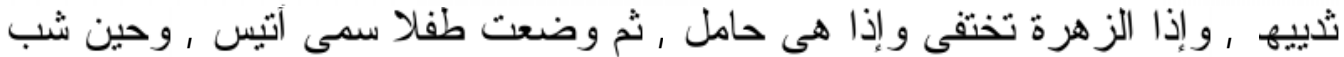

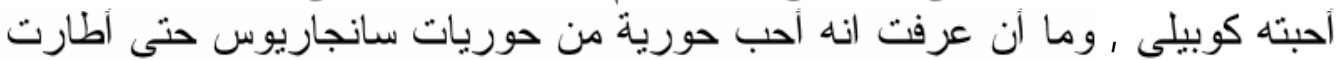

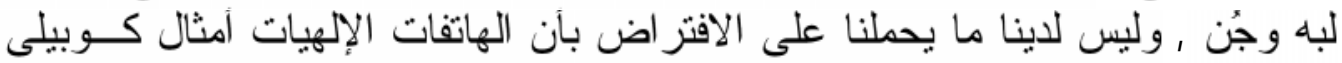

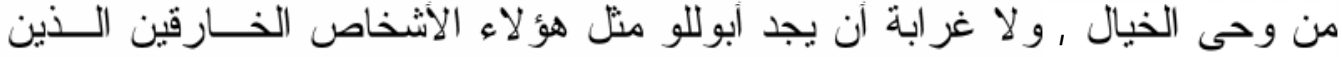

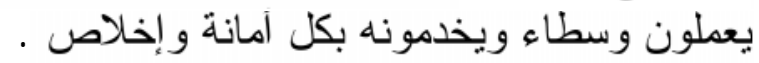

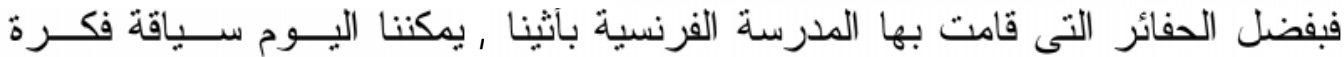

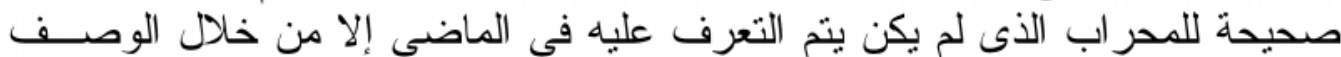

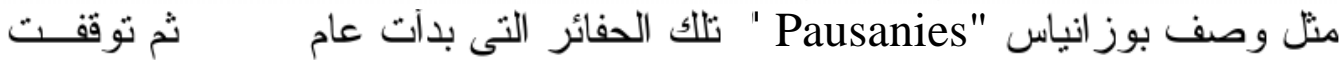

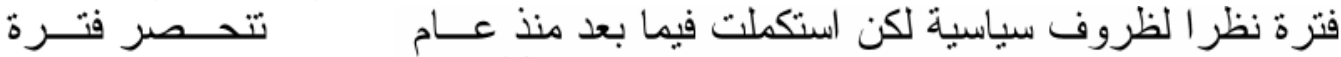

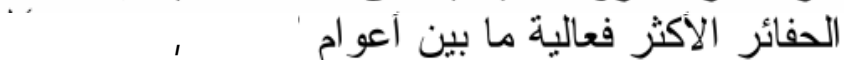
وصف للمنطقة المقدسة أو الحرم المقدس بلدلفي من خلال ما تم اكتشاقه في الحفائر:

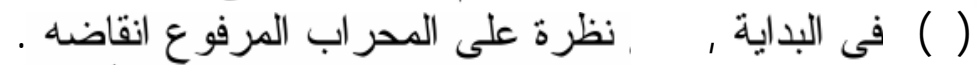

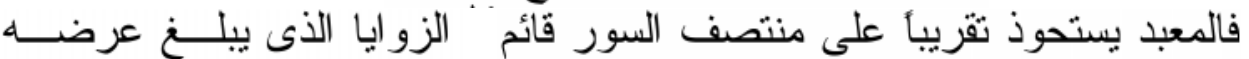

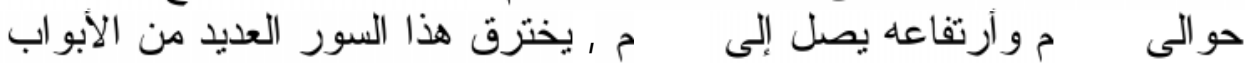

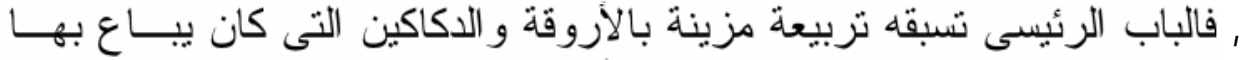

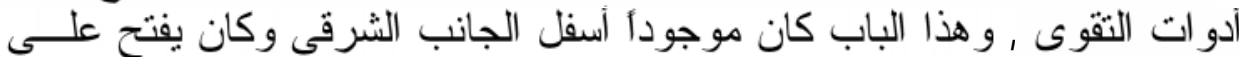

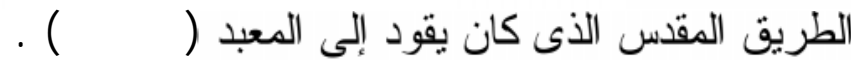

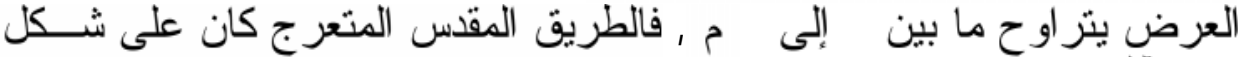

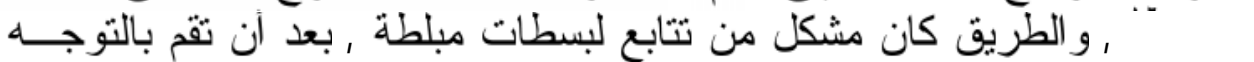

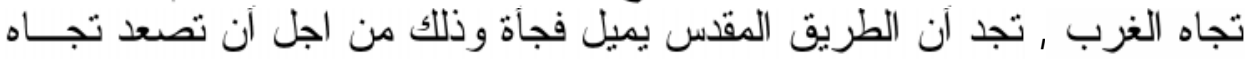

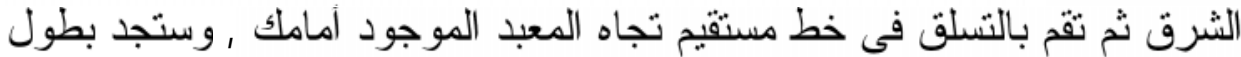

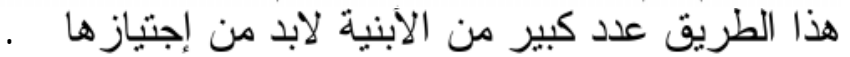

13 - Williamson, op.cit., P. 135

14 - Burguet, E. , " Fouilles de Delphes Exécutees par ordre du Gouvernement Français et publiees, sous la direction de TH. HOMOLLE avec le concours des directeurs de L' Ecole francaise ( en cours de publication .

15- Winter , F. E.,"Greek Fortifications , Routledge \& Kegan Paul ",( London , 1971 )P. 30- 31

16 - Bourguet, op. cit, P. 11 


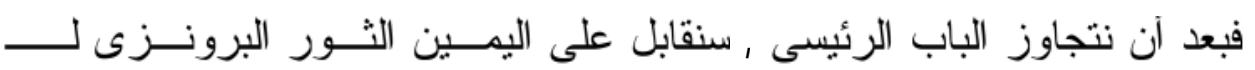

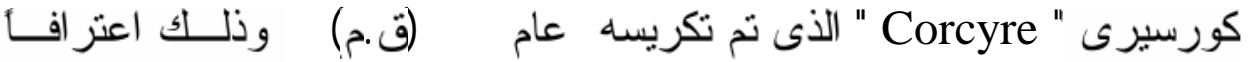

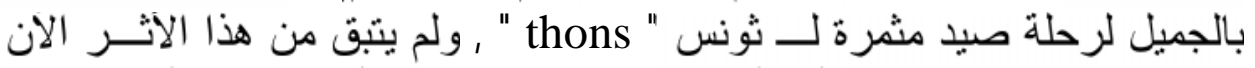

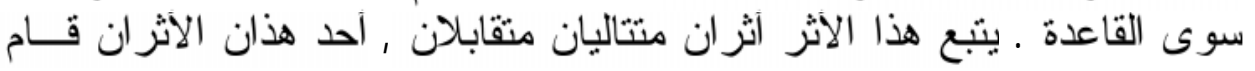

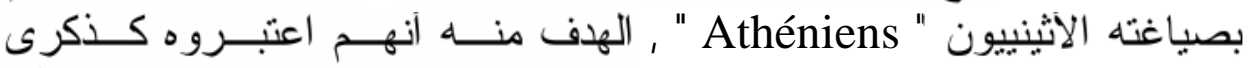

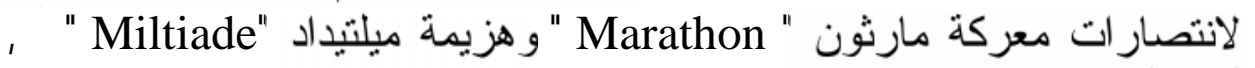

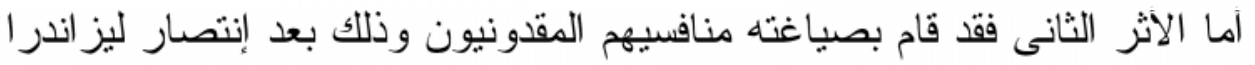

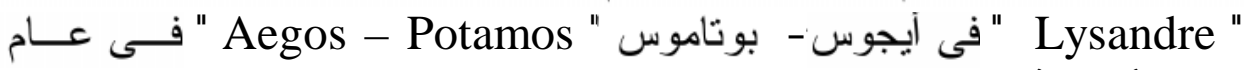

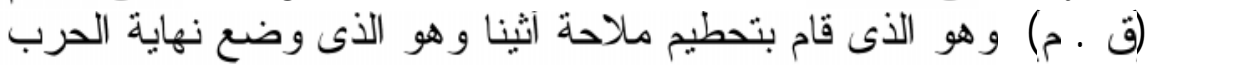

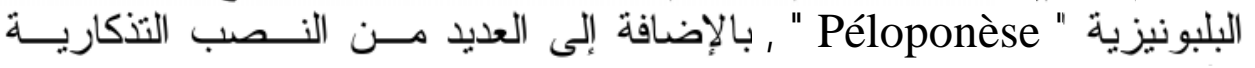

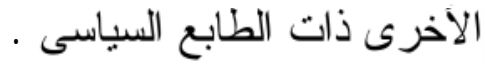

إذا استمرينا فى الصعود تجاه المعبد فسنقابل الطريق المقدس و آبنية صغيرة لها لإنا

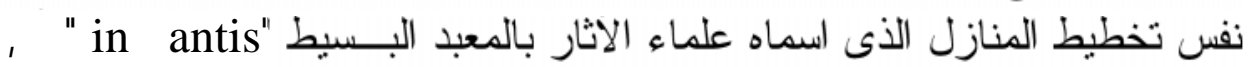

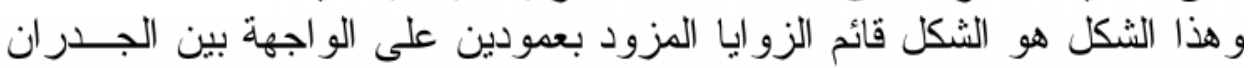

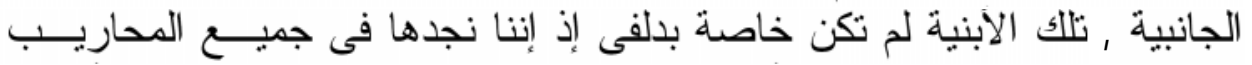

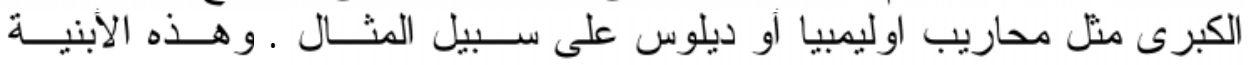

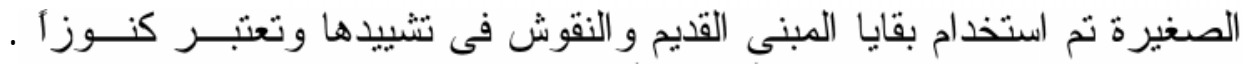

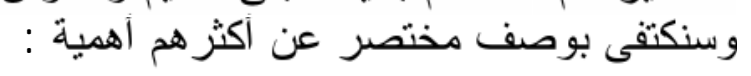

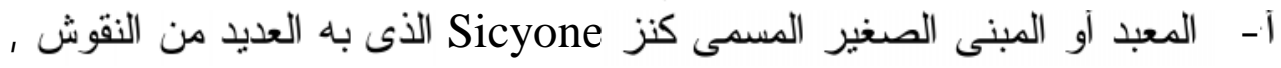

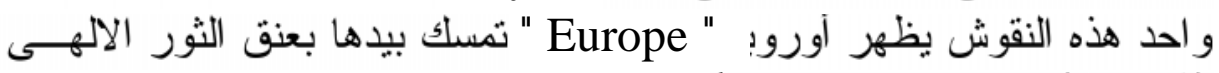

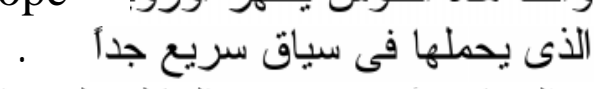

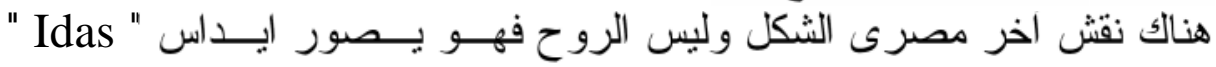

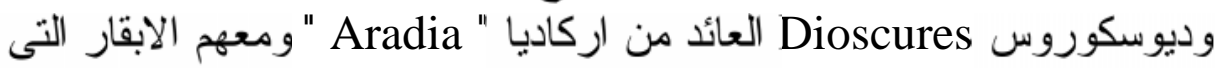

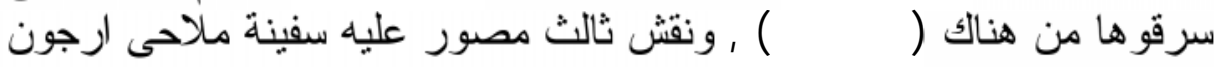

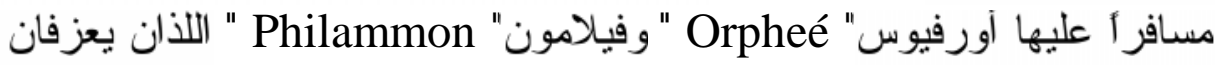

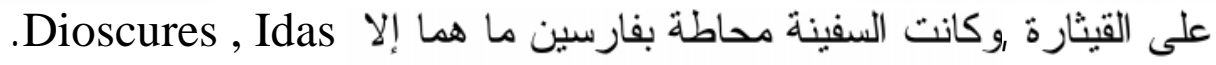

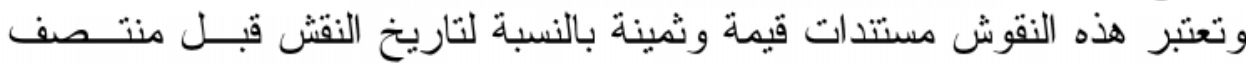
القرن السادس حيه انه تظهر بر اعة التعقل .

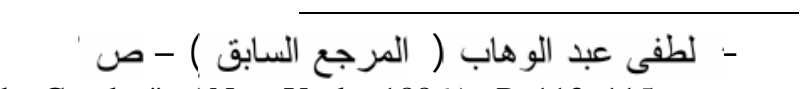

18 - Guerber, A.H ., " The story of The Greeks " , ( New York , 1886 ) , P. 113, 115

20 - Dillon, op . cit ., P . 103

19 - منى عبد الغنى حجاج ( المرجع السابق ) - ص مr 
علينا آن نتذكر آن النقش اليونانى استمر لمدة ثلاثثة ارباع من القرن حيث قــــام بتتفيذ العديد من الأشكال التى نعشقها و التى لم تتوصل إلى اليها الفنون الاكثر قدما -

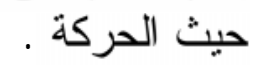
ب- الاكثر أهية ايضا كنز Siphniens الذى يلى كنز Sicyone من حيث الاهمية،

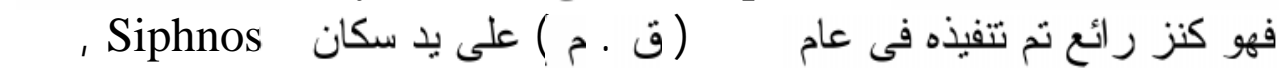

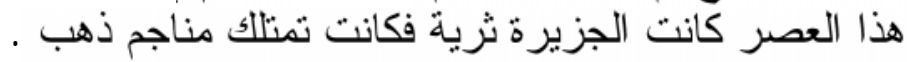

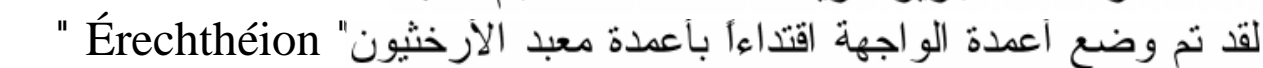

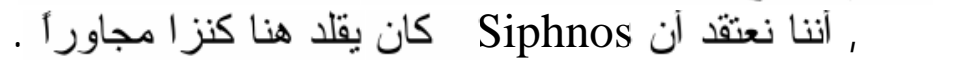

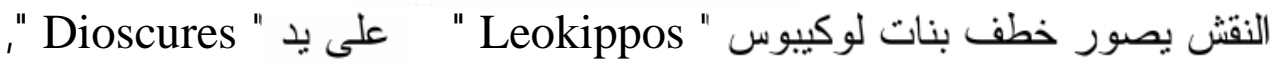

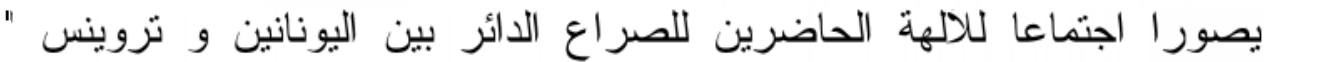

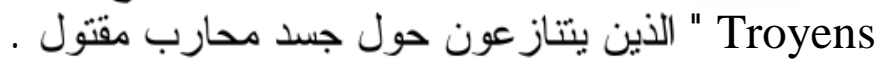

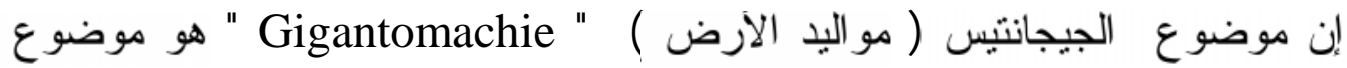

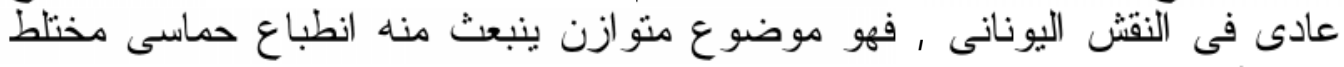

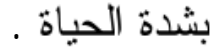
لكن هذه النقوش ذات طابع مركب , كما بها طابع الحياة و النضارة الذى يجب مقارنته

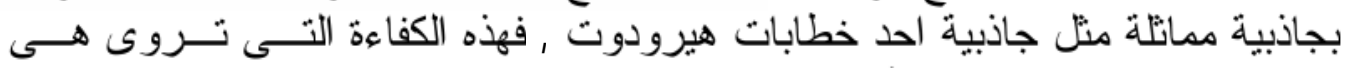

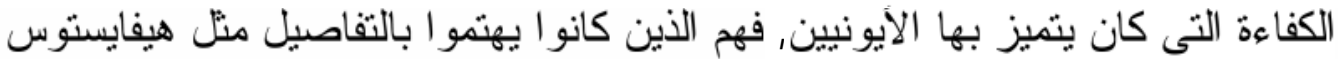
" " Héphaistos"

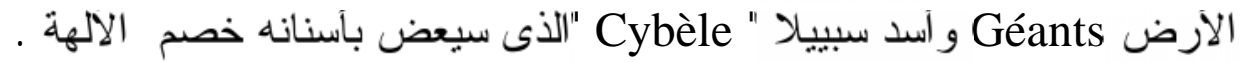

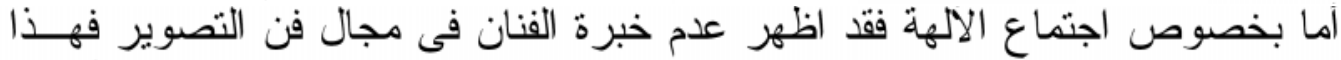

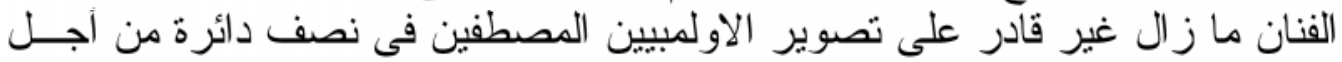

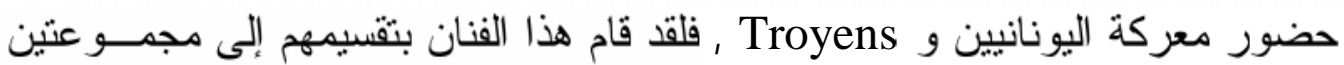

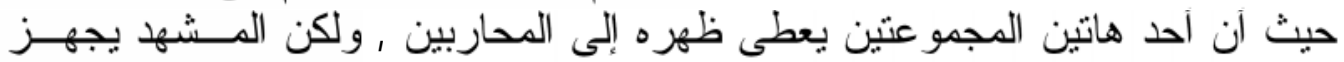

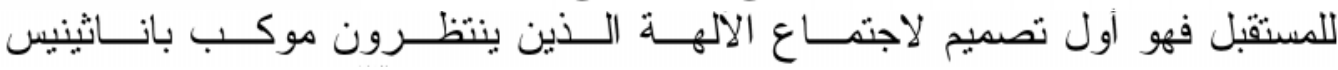

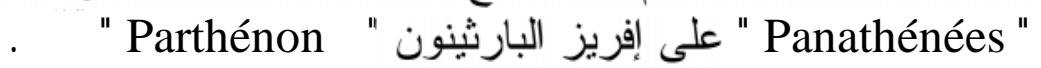

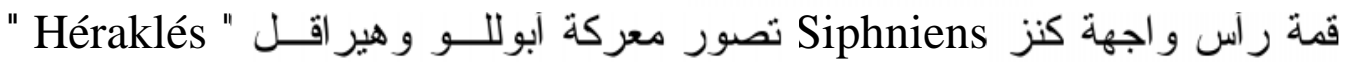

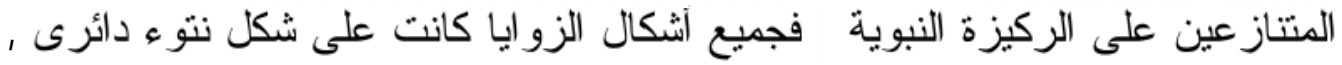

21 - Robertson, S.D ., " Greek \& Roman Architectur " , ( Second Edition ), ( Cambridge , University press , New York , 1929 ) P. $128-129$

22 - Decharme , P. " Mythologie de la Grèce antique ", Cinquieme edition Paris ), P. 107

23 - Hambidge, J., " The Parthenon and other Greek temples, Their Dynamic symmetry ", ( New Haven , 1924 ) , Fig . 17

24 - Dillon, op . cit ., P. 190 


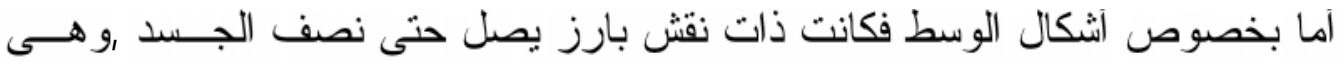

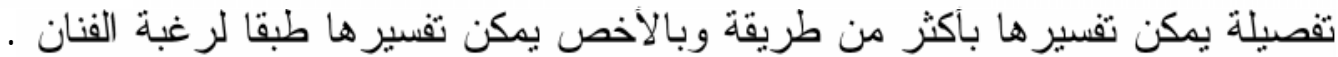

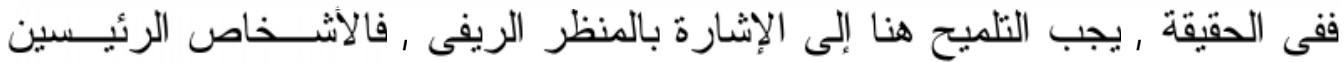

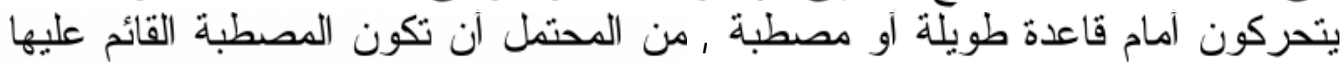

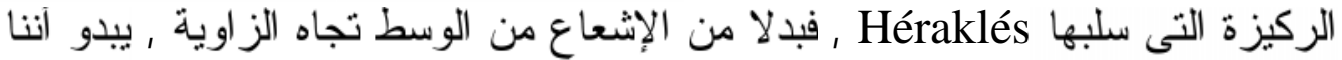

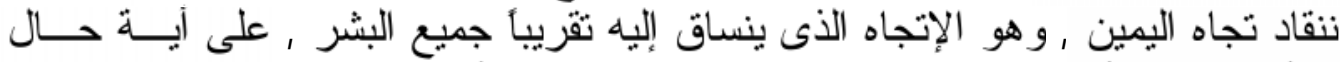

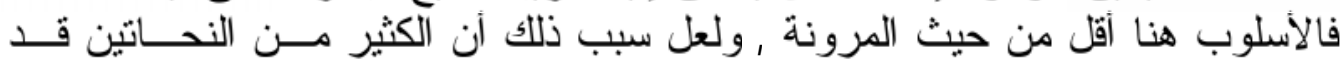

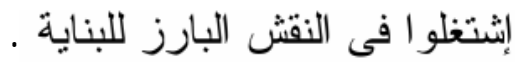

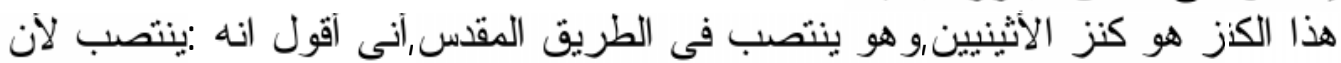

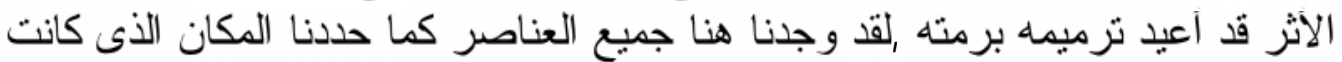

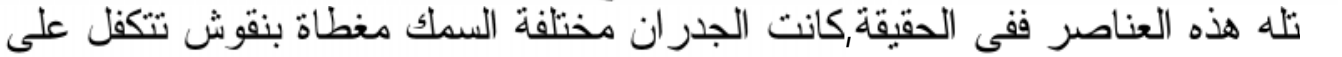

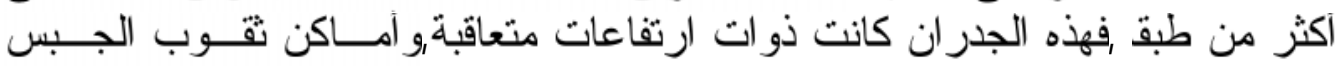

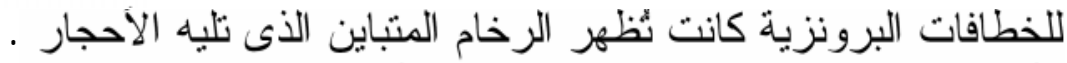

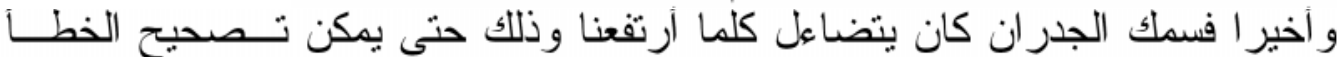
البصرى الذى يظهر مائلا من الخار ج,فبمقتض Pausanias Marathon

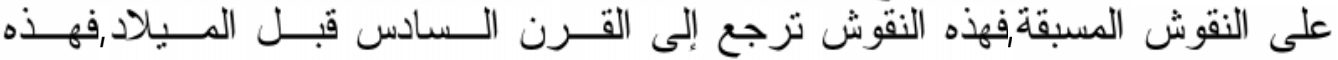

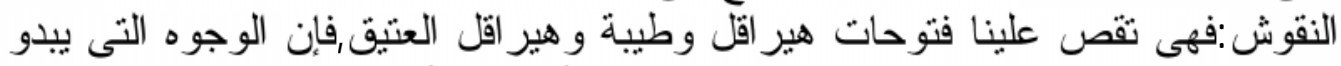

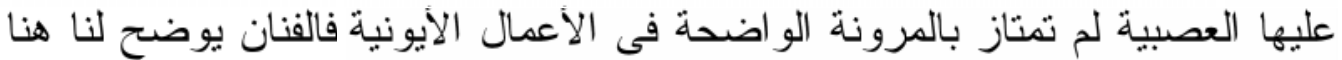

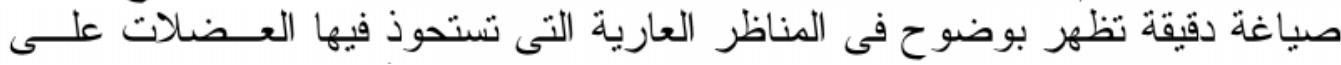

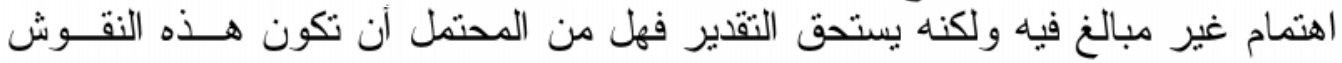

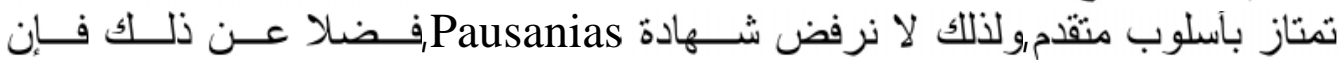

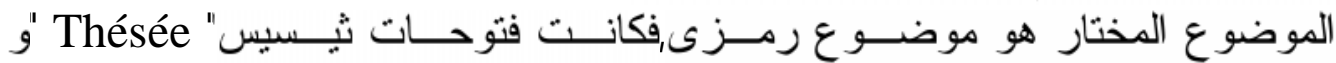

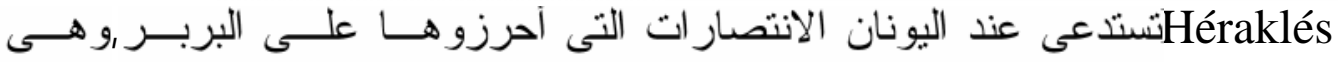

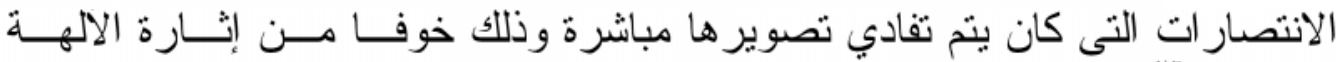

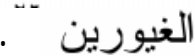

فإن النحت البارز الذى نر اه فى شكل (7) يظهر لنا Thésée منتصر أ على انتيوبى '

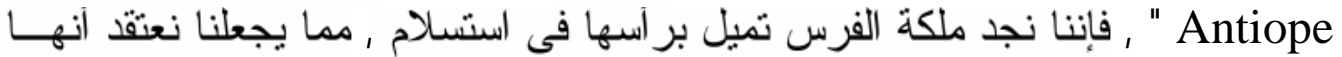
قد وقعت فى غر ام المر اهق القوى الذى انتصر عليها وها هي أسيرته الان .

25 - Pausanias, " La Gréce translated by Périégèsis " X*

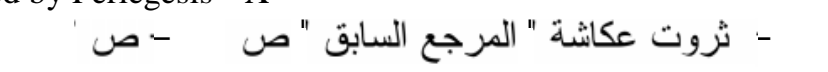


(ع) و استكمالا فى الصعود تجاه المعبد ـ نجد على البسار من أسفل البناء قائم الزو ايا ,

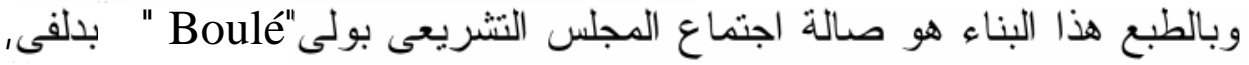

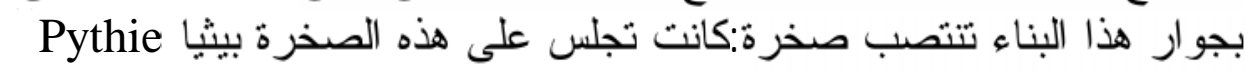

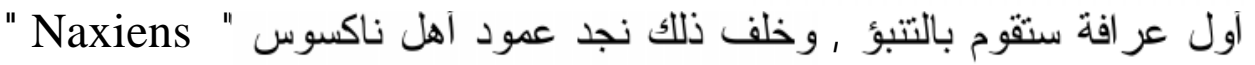

$$
\text { ومحراب Gaia. }
$$

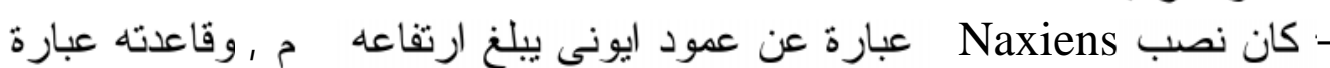

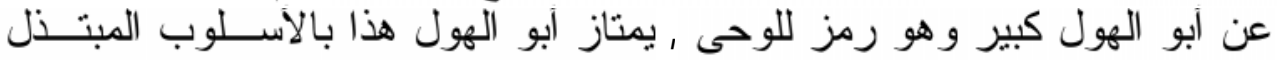

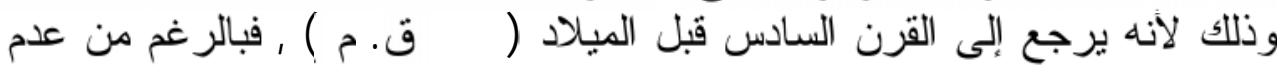

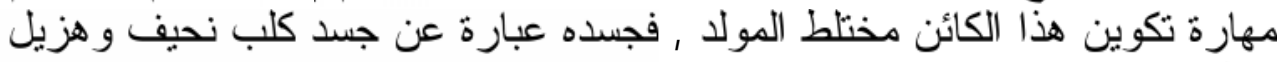

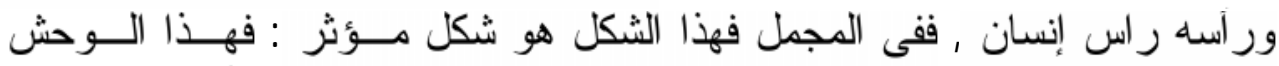
العصبى ذو الوجه الغامض و القوى , الجن الحقيقى للموت , يبدو كأنه يستعد ليثب

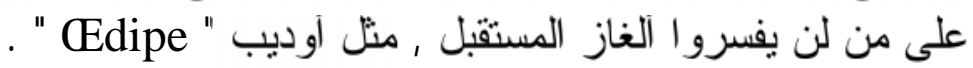

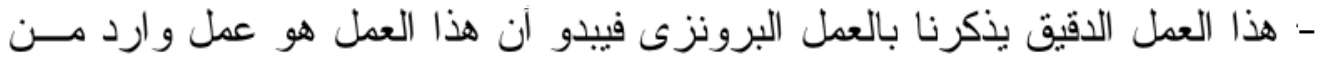

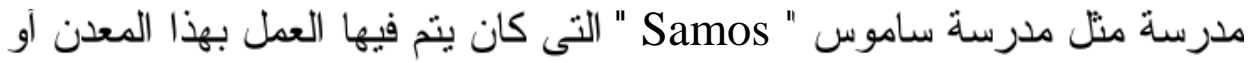

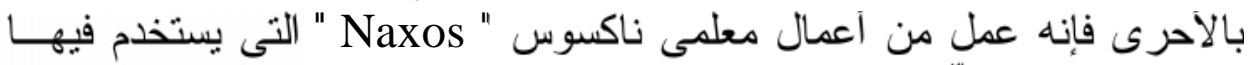

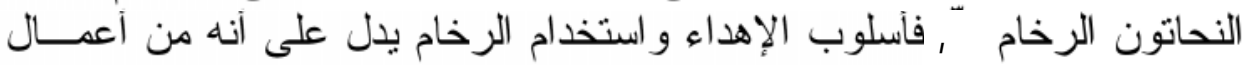
Naxos

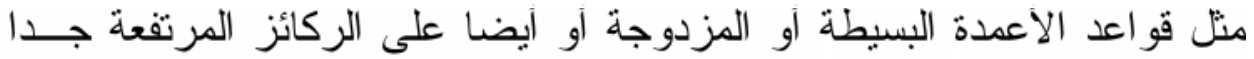

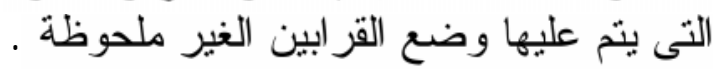

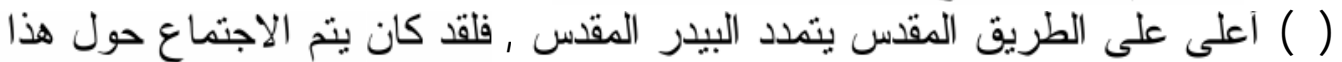

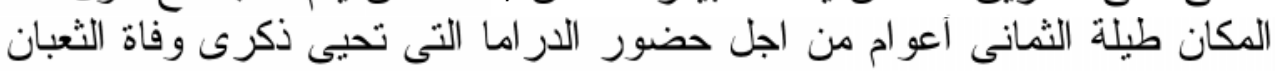
Python

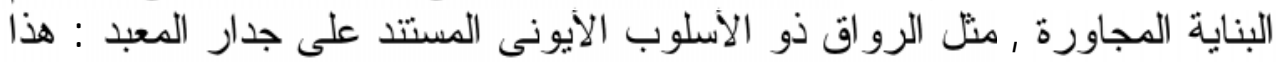

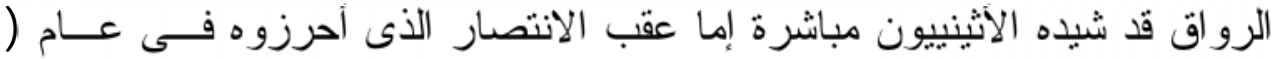

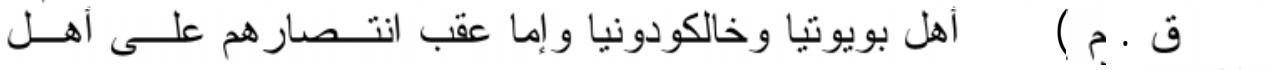
سلاميس " ا"ن.

28 - Dillon, op . cit ., P. 77

$$
\text { IOH - منى عبد الغنى حجاج ( المرجع السابق ) - - مV }
$$

29 - Petrie , F. W. M ., " Temple of Apollo, Maucratis , details and column " , ( Restored ), ( Naukratis, 1886 ) PL. 10

30 - Bieber, M. , " The sculpture of the Hellenistic age " , ( New York, 1955 ), P.P 9FF

31 - Picard, CH. , costemesselière, LA DE P., " La Sculpture greeque a Delphes ", ( Paris , 1929 ) , P. 48 


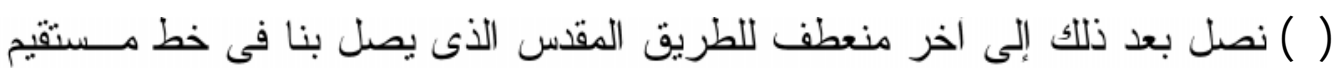

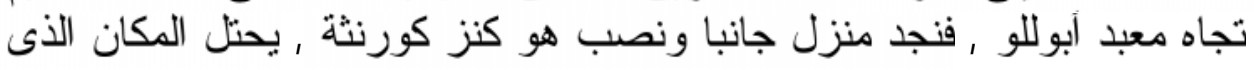

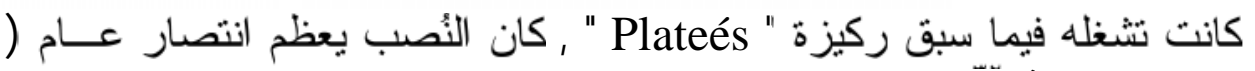

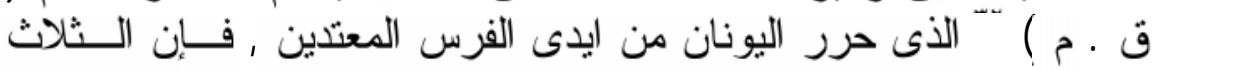

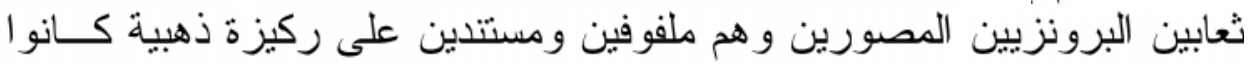

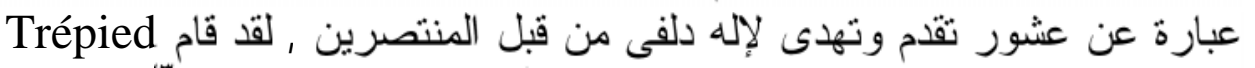

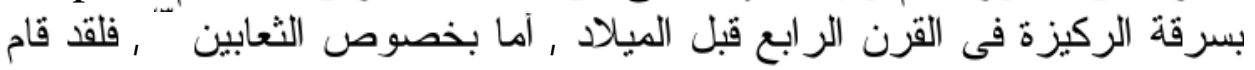

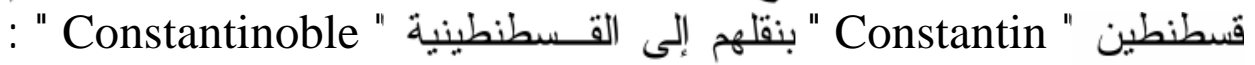

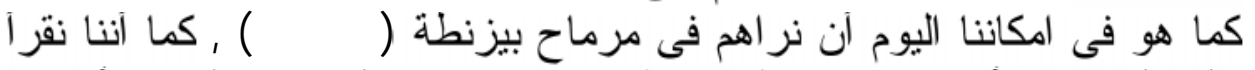

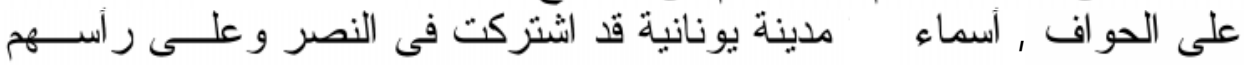

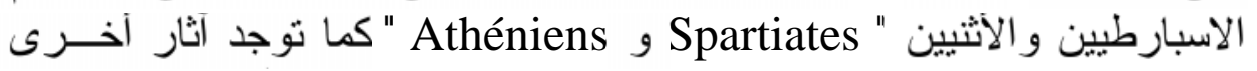

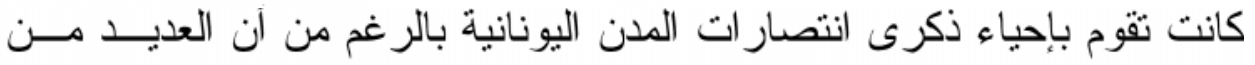

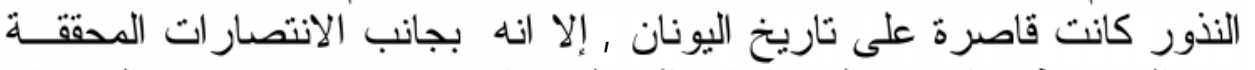

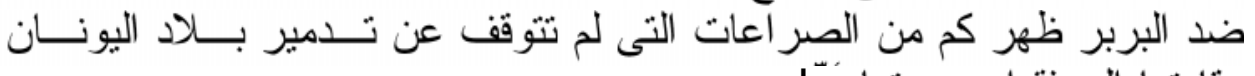

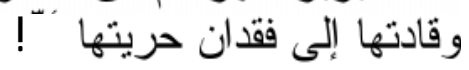

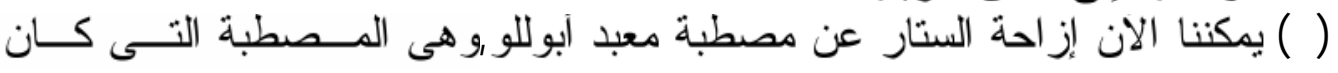

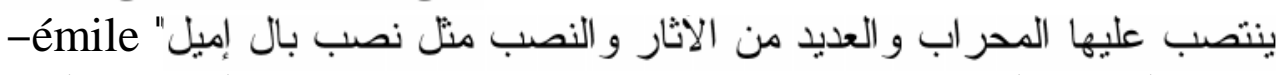

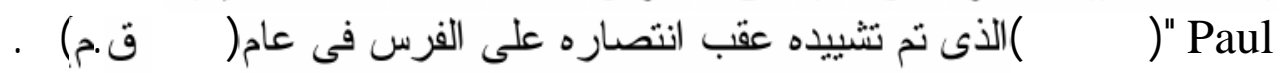

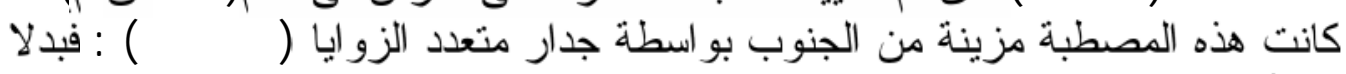

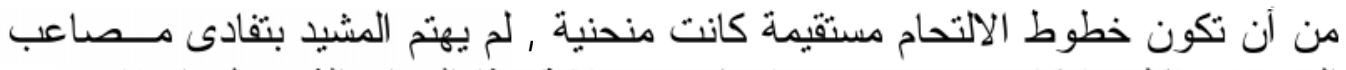

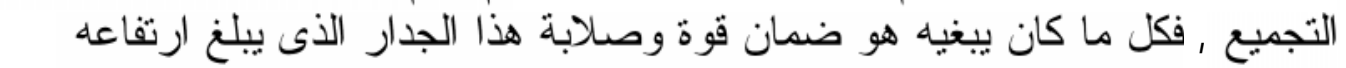

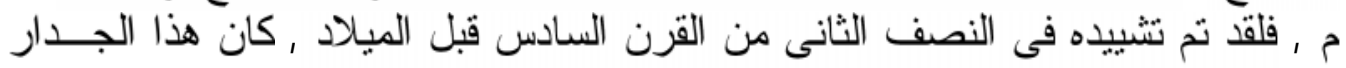

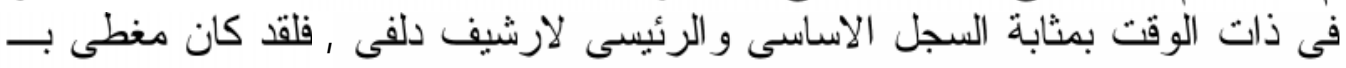

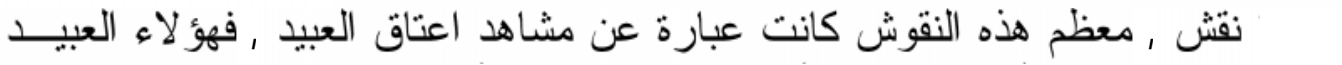

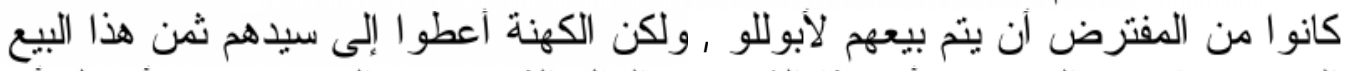

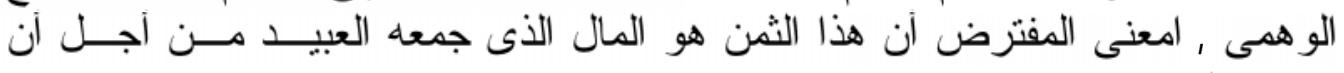

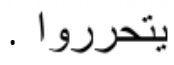

33 - Graindor, P. " Delphes " , ( Le Caire , 1930 )

$$
\text { r r - لطفى عبد الوهاب ' المرجع السبق ' ص سّع }
$$

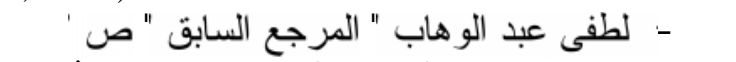

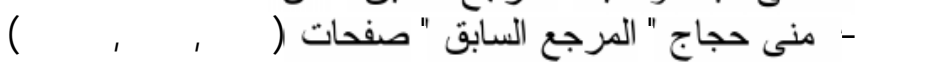




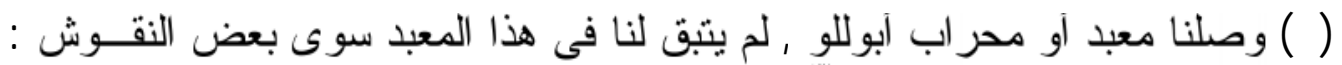

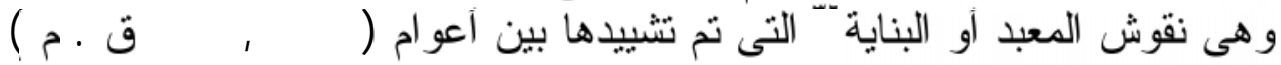

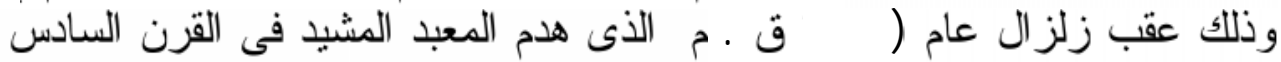

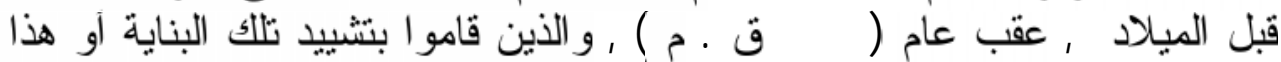

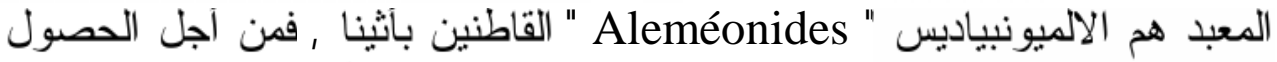

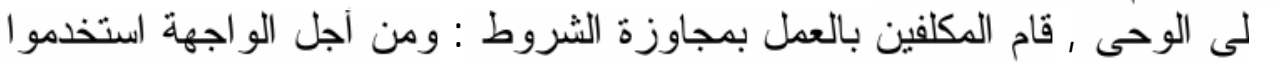

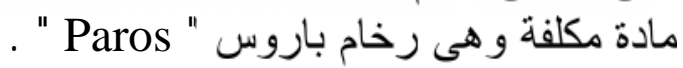

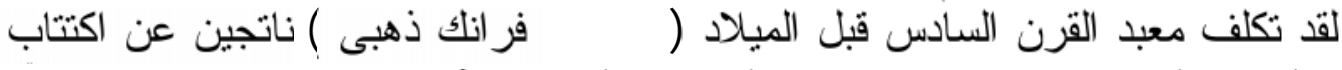

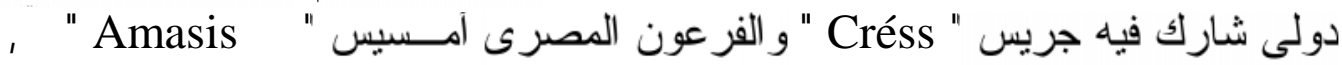

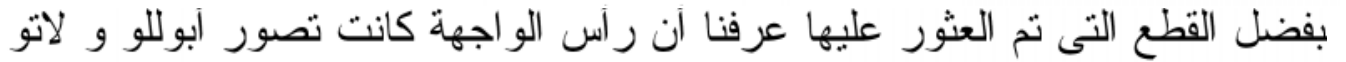
Amasis ," Léto "

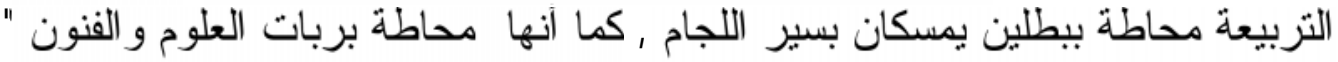

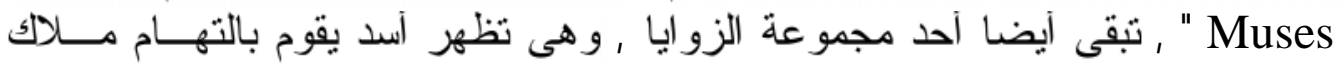

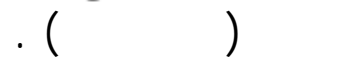

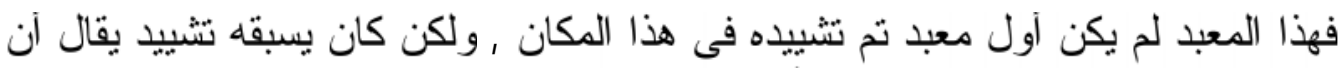

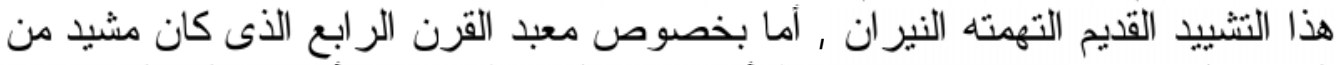

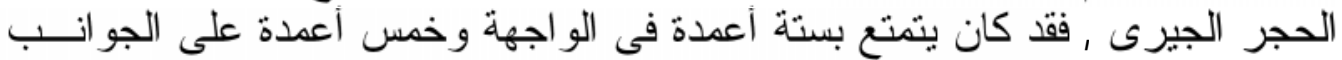

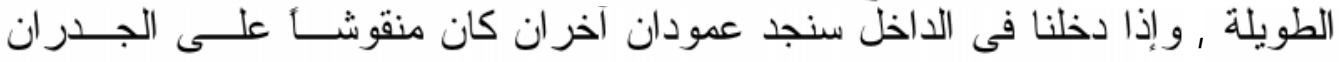

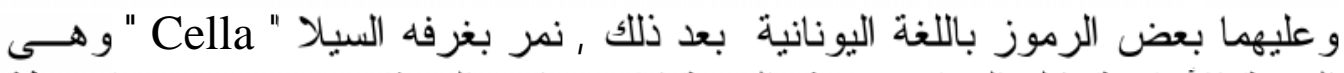

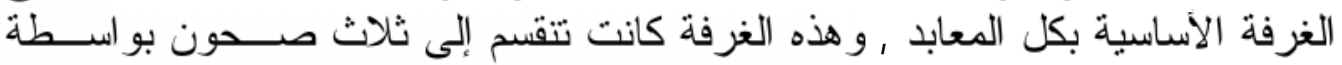

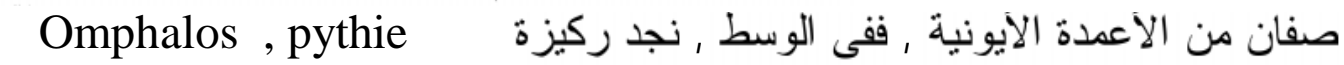
, وفى صالة مجاورة , نجد المستشارين فى انتظار إجابة الإله , فى النهايــة , خلــــ

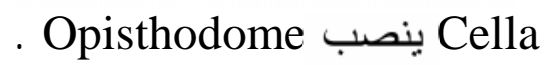
كانت رؤوس الو اجهات مزينة بالنقوش , وهم اعمال لمعلمين اثثنيين , لم يتم العثــور

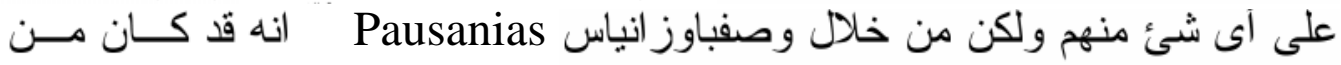

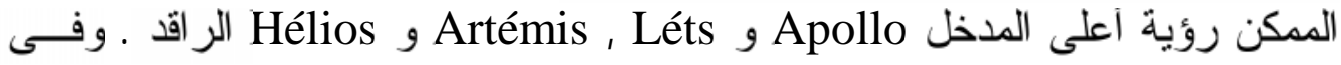

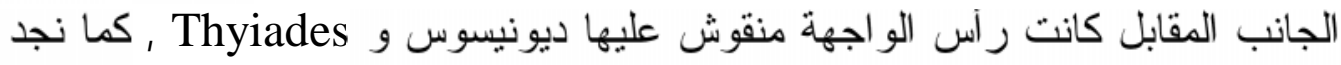
تروس قد تم اخذها من الفرس فى Plateésوكنلك نجد تروس ماخوذة من Gaubois.

36 - Petre, op. cit, PL 11

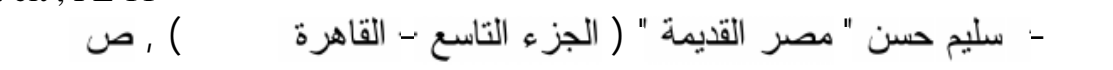

38 - Bourguet, op. cit ., P. 34

39 - Dausaniads, op ., cit ., $\mathrm{X}^{*}$ 


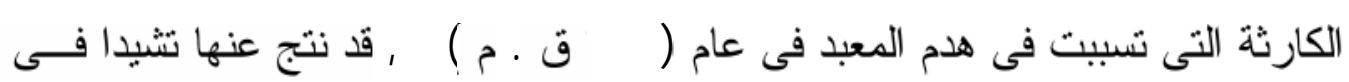

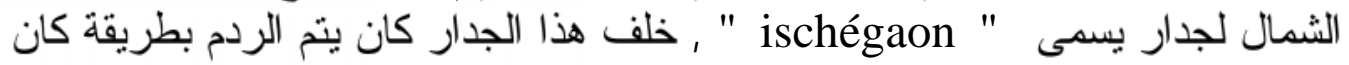
الهدف منها إخفاء قو الب الاحجار المتساقطة من حجر Phédriades وكذلك من اجل الجل

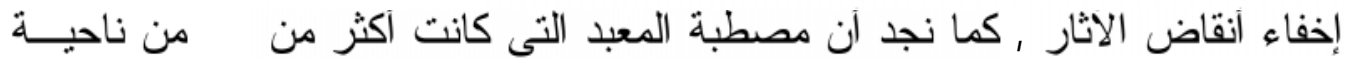

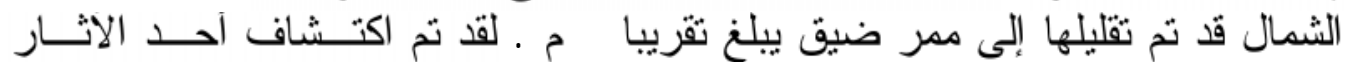

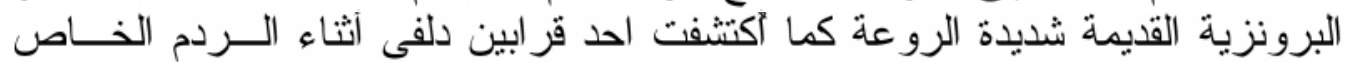

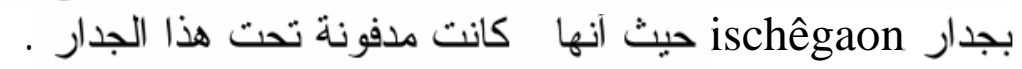

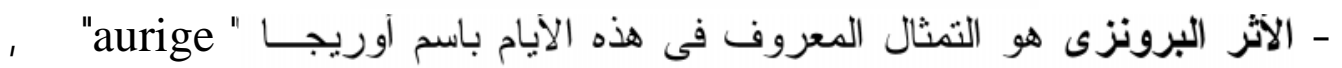

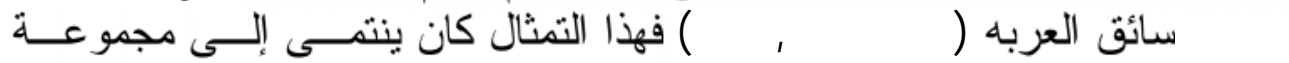

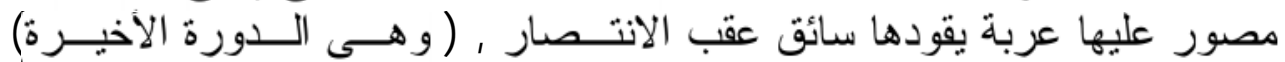

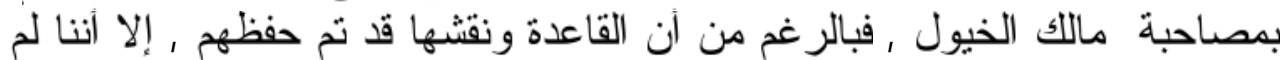

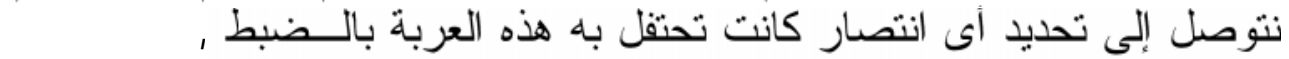

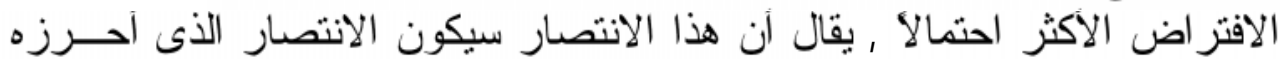

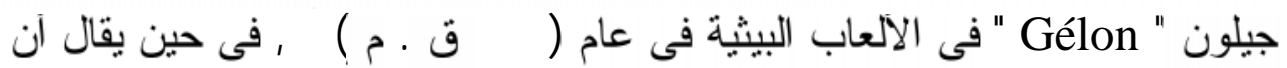

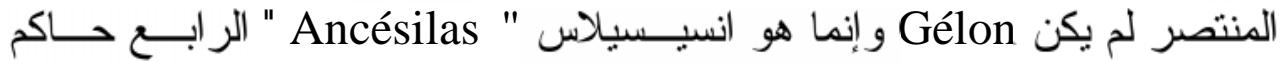

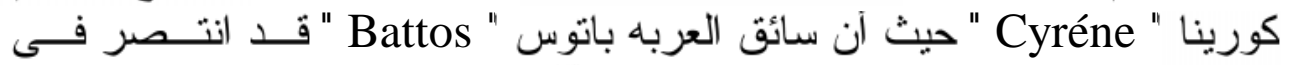

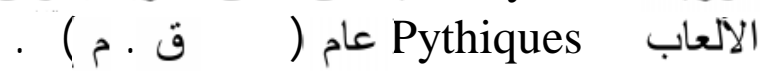

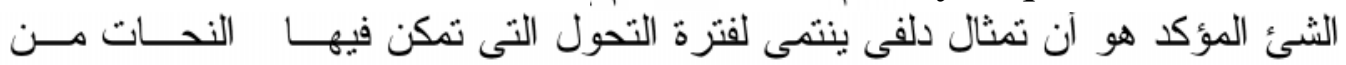

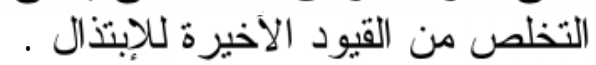

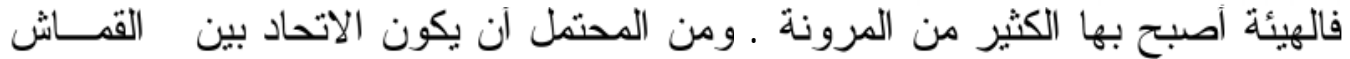

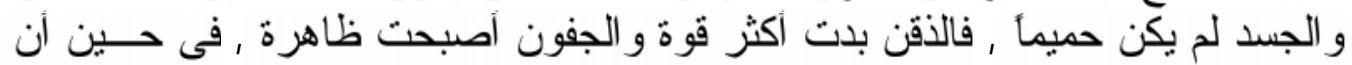

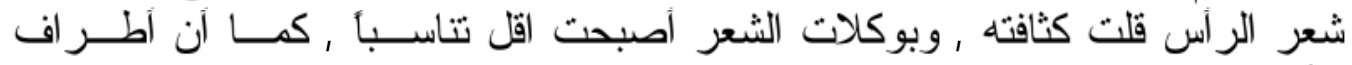

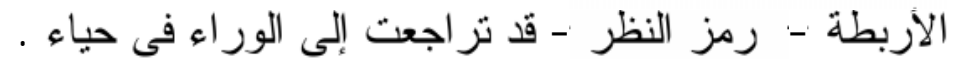

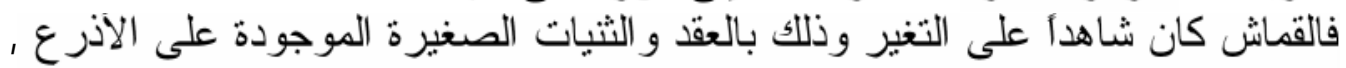

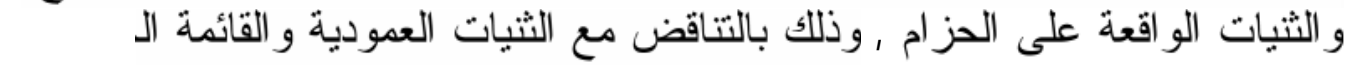

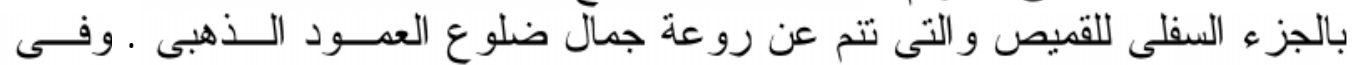

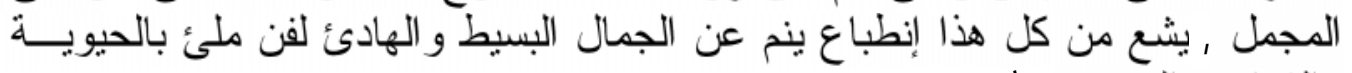

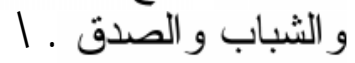

40 - Pontow, op . cit . t . IV et suppl IV

41 - Picard et costemesselière, op . cit ., P. 35

42 - Harris . H. A., " Greek Athletes and Athleties ", ( London, 1964 ) P. 270

43 - Graindor, op . cit ., P . 22 
إذا اردنا آن نضع اسم فنان على هذا العمل : فإذا كان هذا العمل عبارة عن بورتزيـهـ

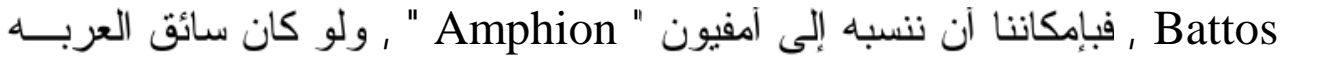
الإلعمل يمكن أن يكون لـ ريجيون ' Rélon

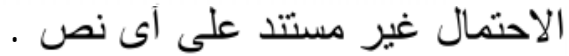

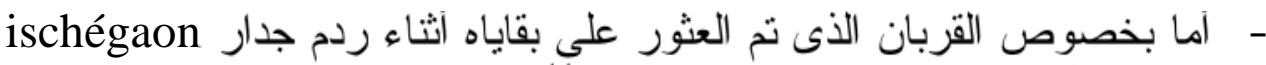

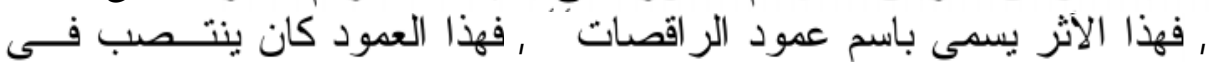

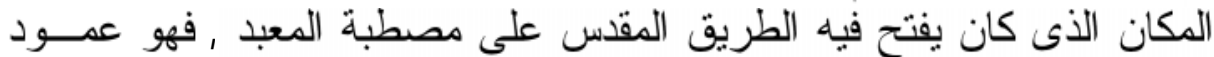

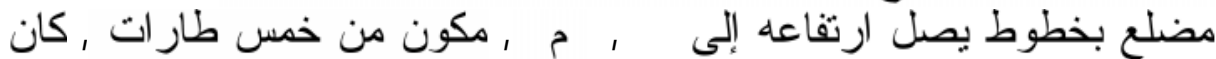

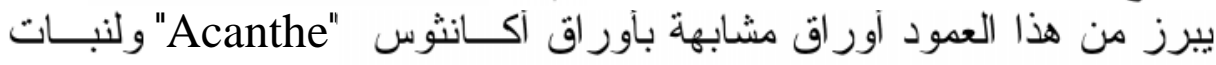

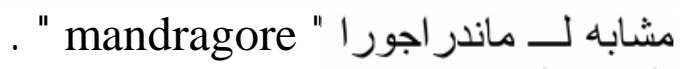

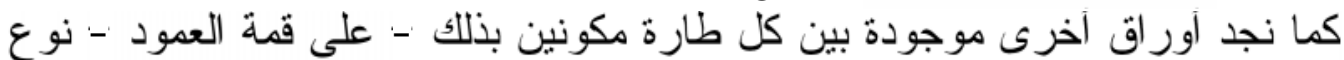

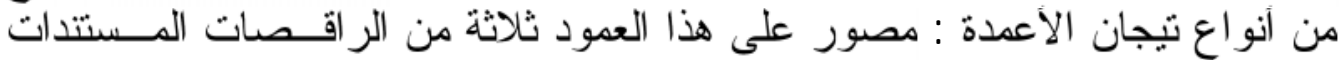

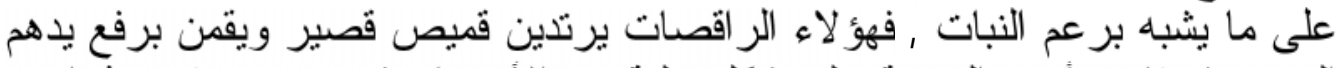

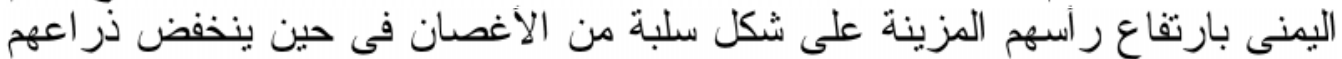
الايسر ويمسكن بطرف الثوب الثفاف , فهؤلاء الر اقصات كن مستندات على الاتى ركيزة ,

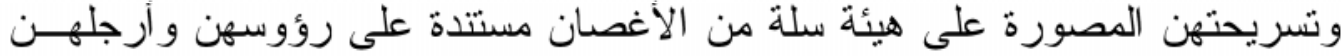

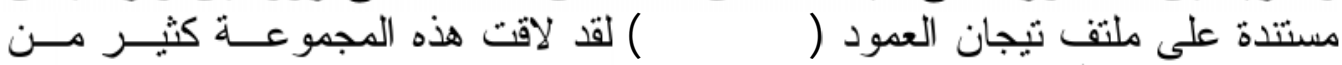

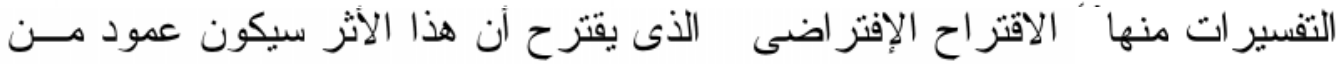

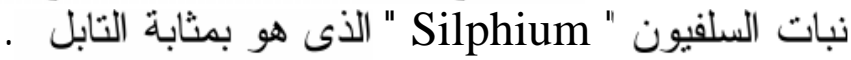

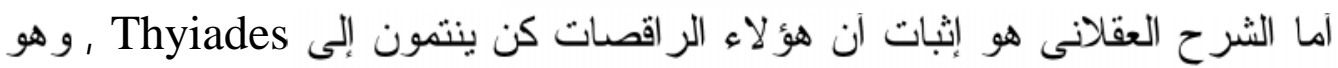

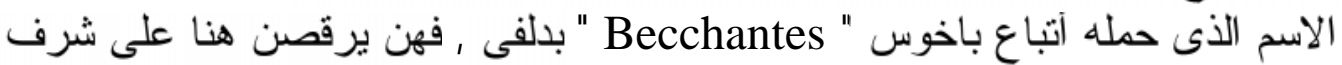

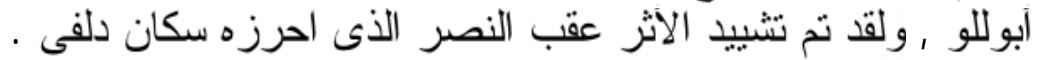

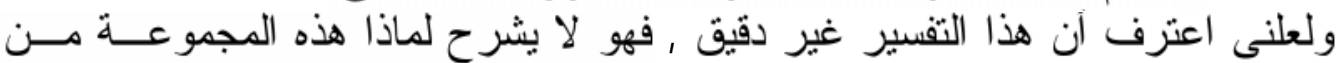

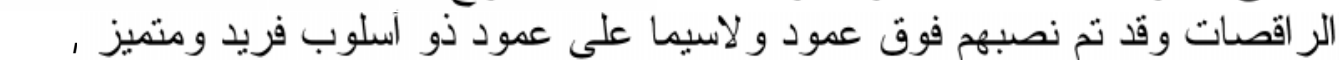

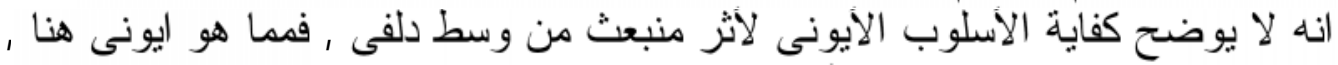

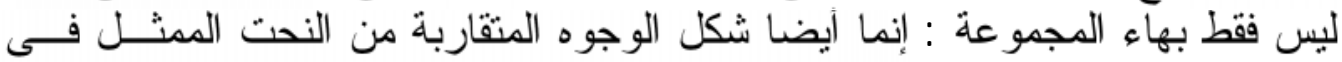

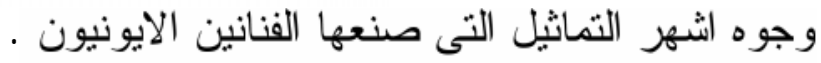

44- Picard et costemesselière ,op . cit ., fig . 17

45- Kirk \& Bentley ." Ptolemaic coim . An introduction for collectore ", ( Toronto , 1995 ), PP . $41-42$ 


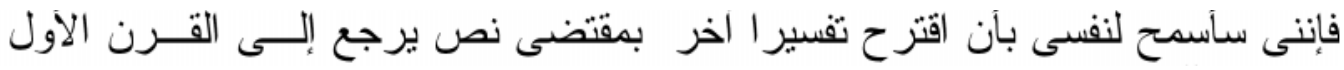

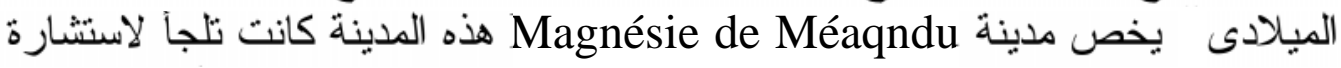

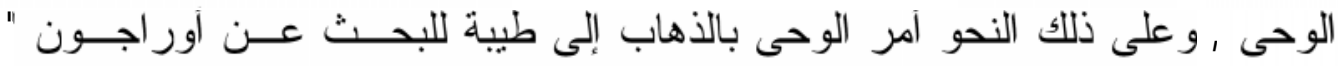

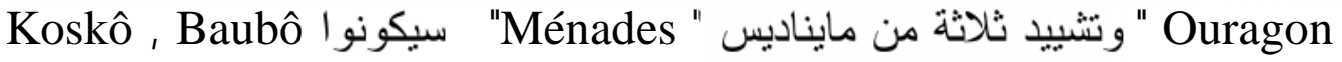

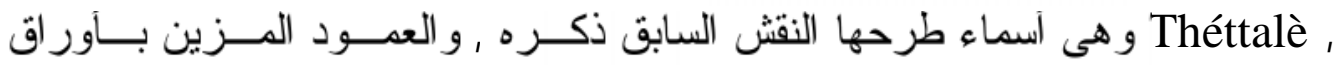

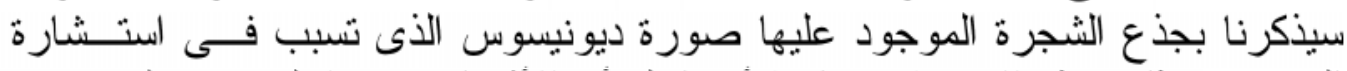

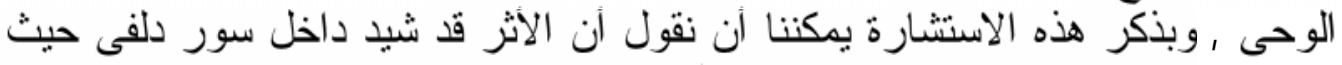

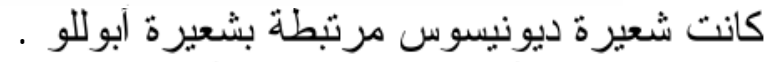

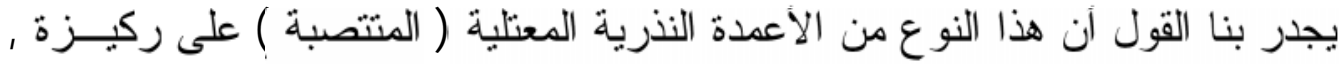

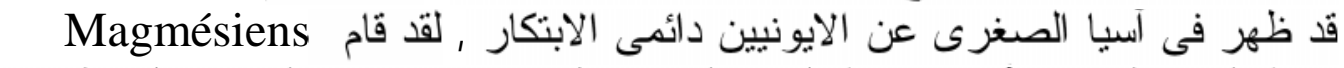

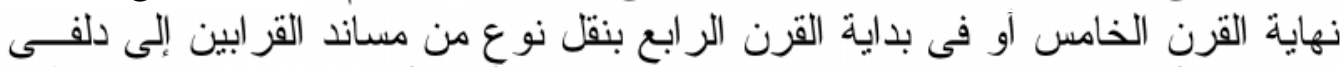

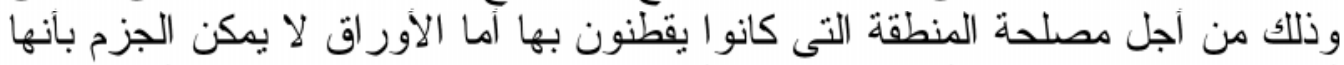

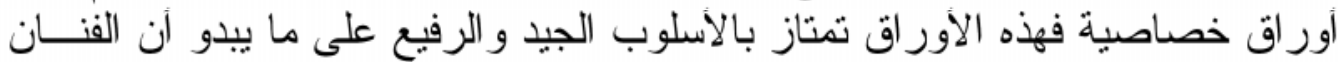

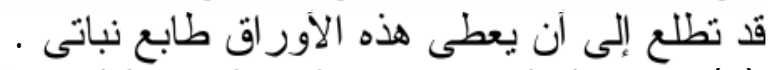

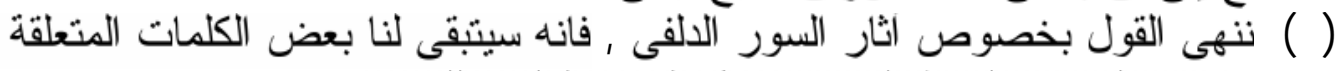

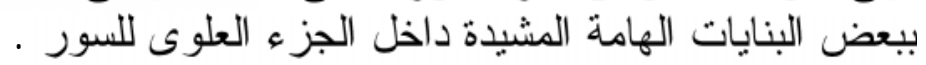

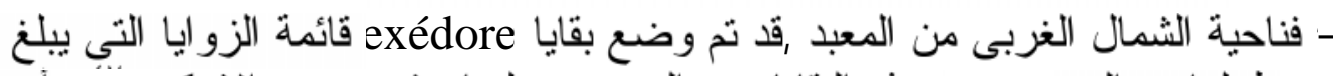

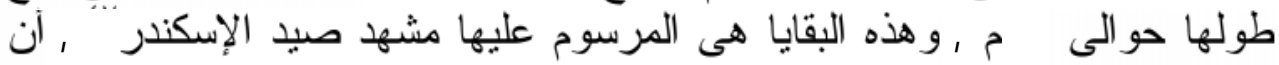

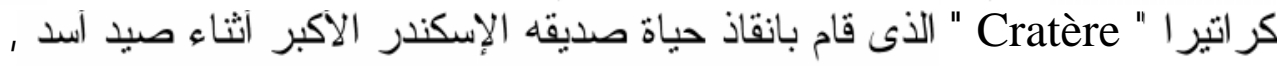

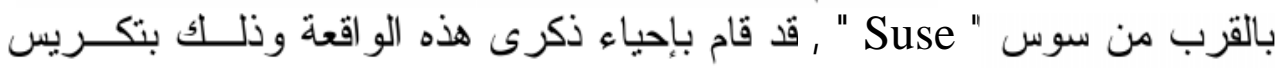

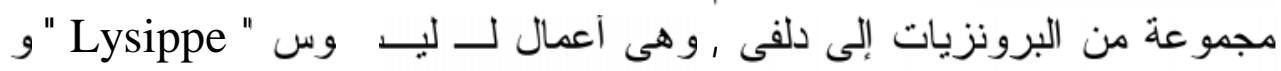
. Léocharès

إننا نرى هنا الملك فى نضال مع الأسد فى حين أن Cratère كان يجرى ور اءع كلابه

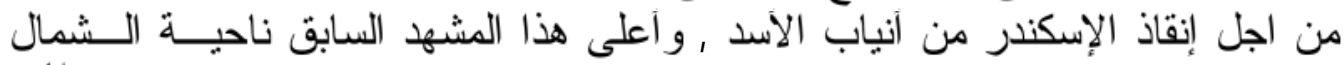

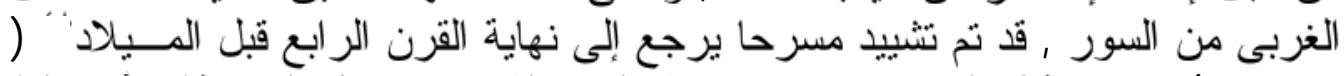

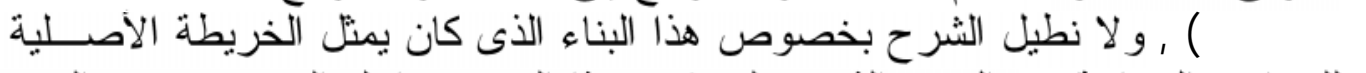

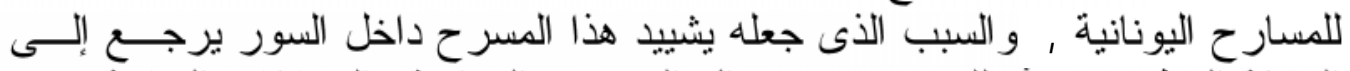
العلاقة الوطيدة بين ابوللو وديونيسوس اله العروض الدر امية و المسابقات الغنائية .

46 - Graindor, op. cit ., P. 25

47 - Guerbr, op . cit ., PP. 52 - 255

1ع - لطفى عبد الوهاب ' المرجع السابق ' لوحة - 1 


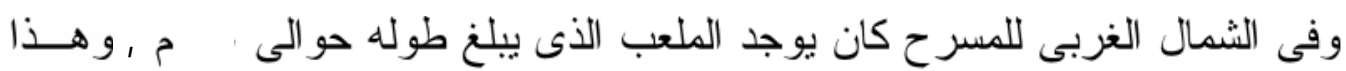

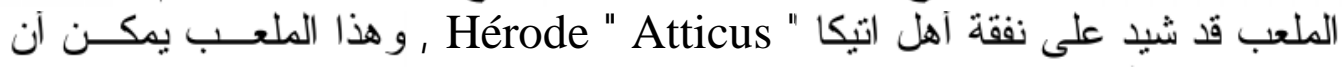

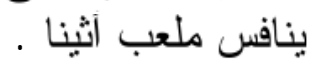

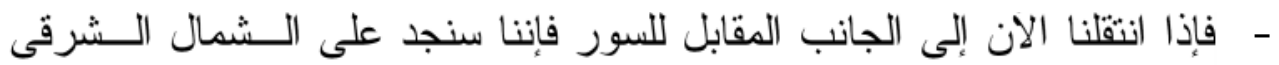

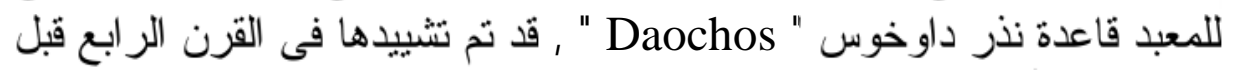

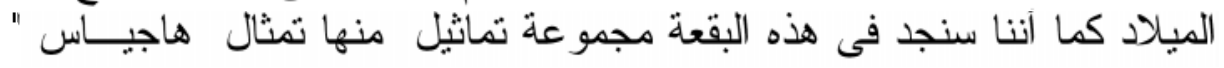
Hagias

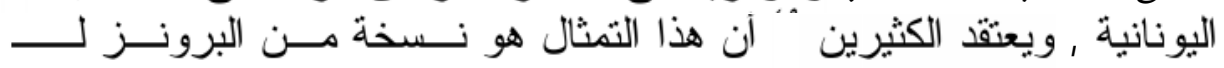

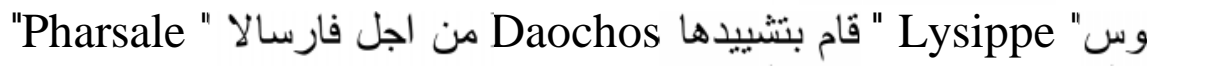

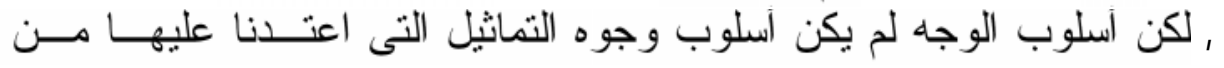

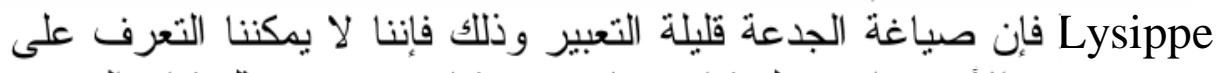

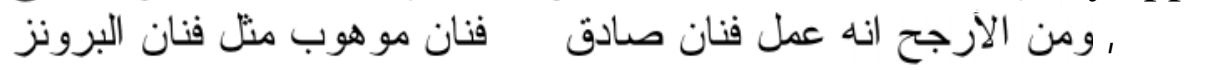

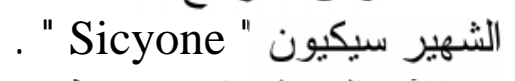

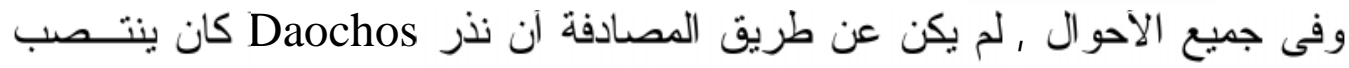

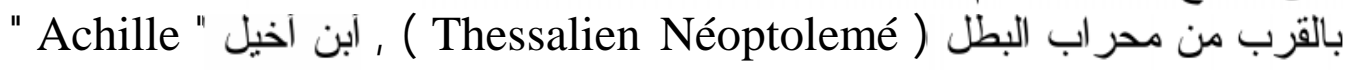

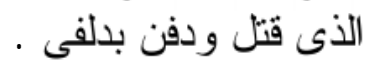

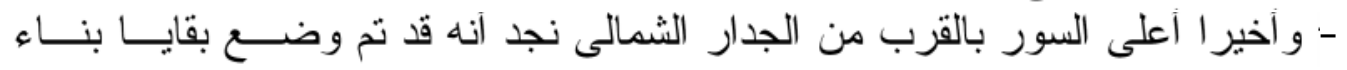
Leshé des Cnidiens

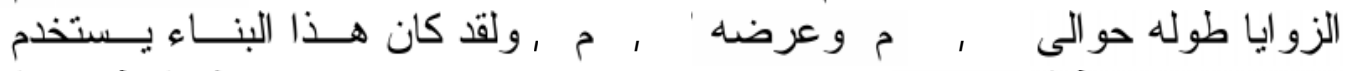

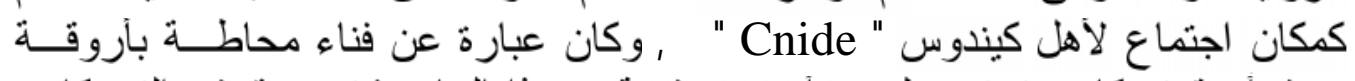

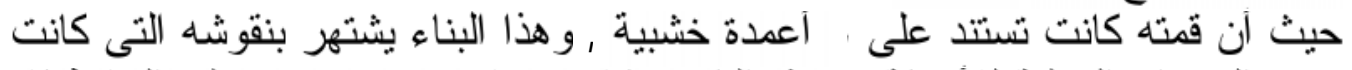
تزين الجدران السفلية للأروقة , وهذه النقوش كانت عانت عبارة عن تصوير على الحائط قام

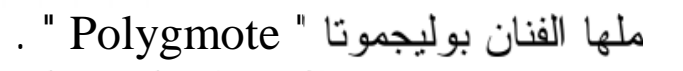
و كانت تصور بعض النعاويذ والهايا النى قام باخذها اليونان الذنين كانو ا يسستعدون

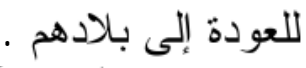

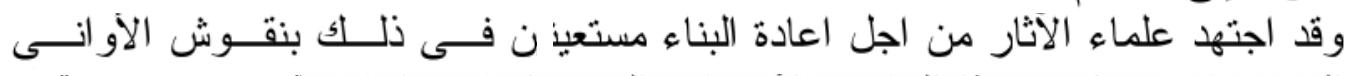

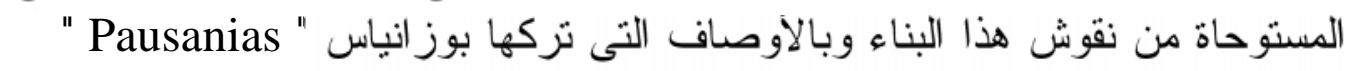
, هذا بالإضافة إلى عدد من التماتل الثخصية كتماثيل الفلاسفة ششكل 17 (1) .

49- Graindor, op . cit ., P. 27

50 - Donald, op.cit. , P. 75

51 - Pausanias, op . cit. 


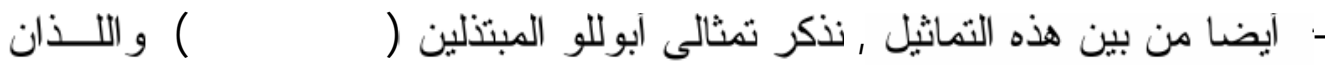

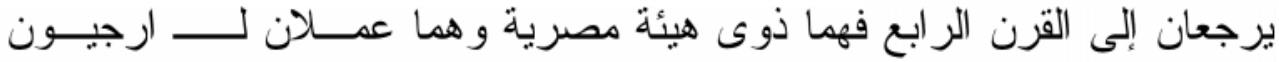

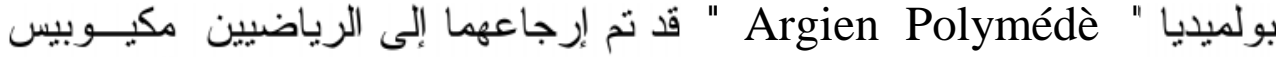

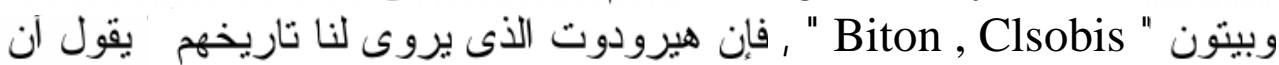

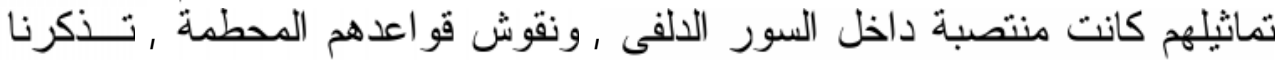

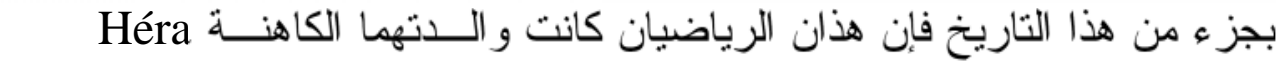

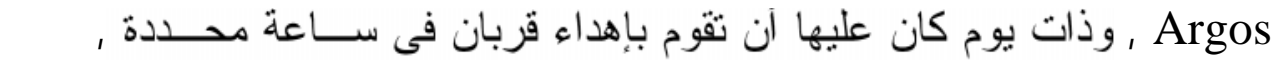

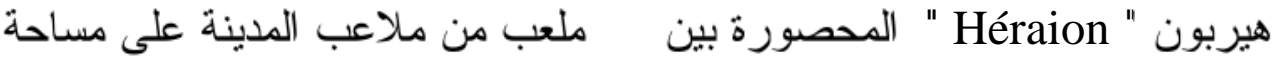

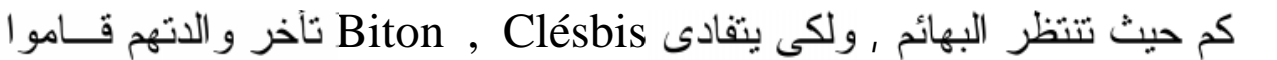
باصطحابها فى عربتهم ,وبذلك تمكنت الأم من تقديم قربانها فى اللحظة المقررة ,

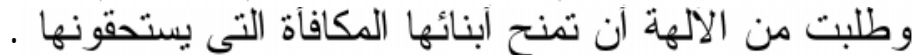

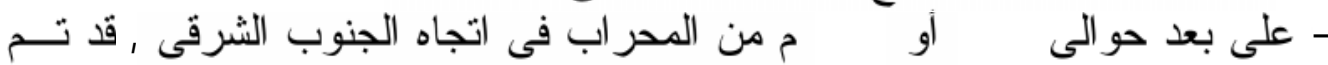

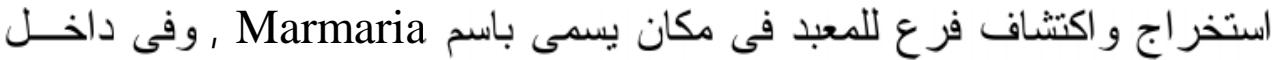

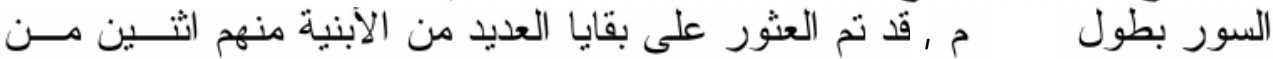

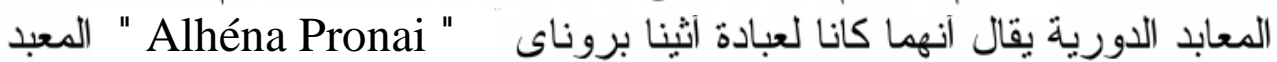

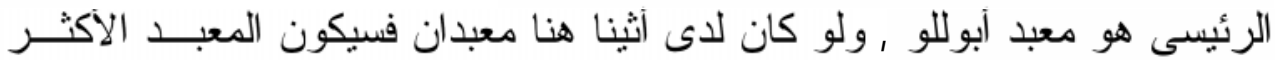

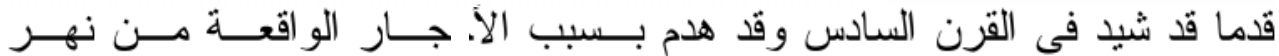

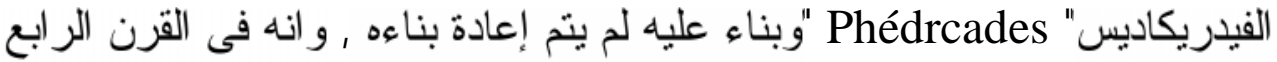

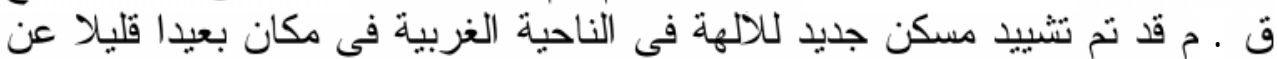

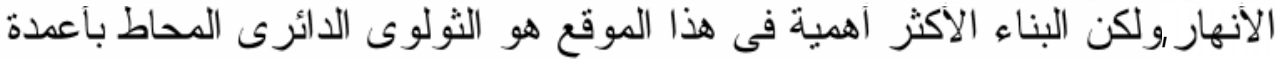

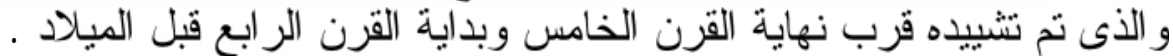

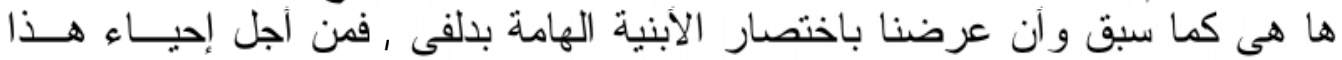

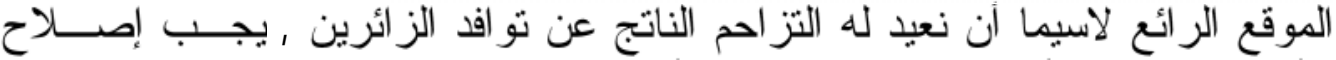

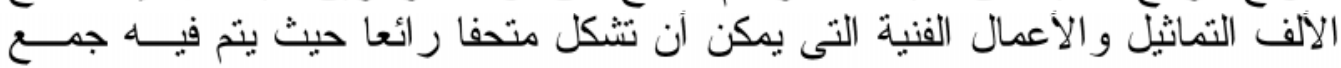

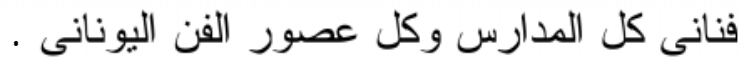
ونحن ننهى الحديث اتنذكر أن حماس الإله أبوللو منتو اصل مع الـــنين يــأتون لزيــارة

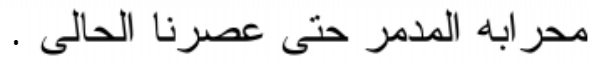

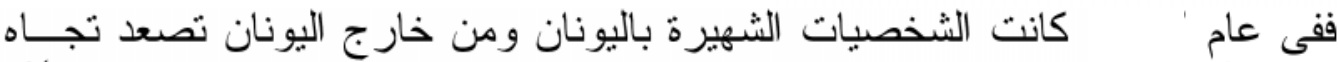

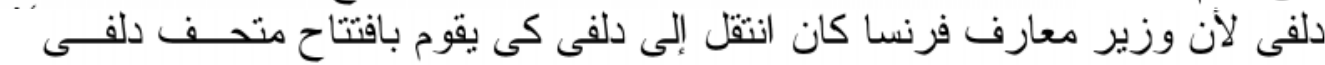

52 - Herodotu, ( Book I - IV ) " translation by Godley " , ( Loeb , class . libi )

53 - Bourguet, E. , " Les ruines de Delphes ", (Paris , 1.14 ).

54 - Poulsen, op . cit., P. 57. 
- مراسات في اثار الوطن العربي -

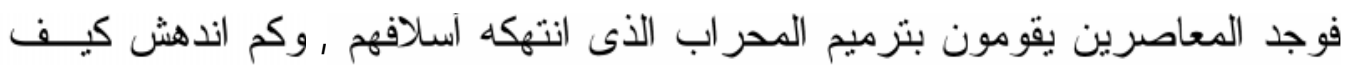

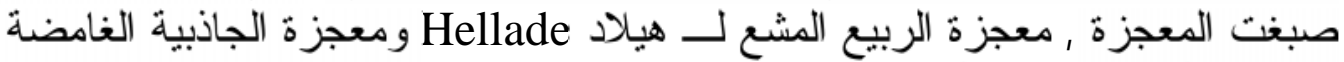

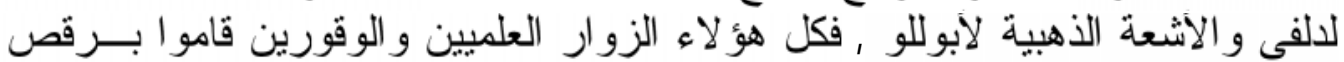

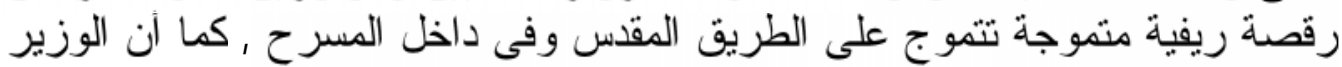

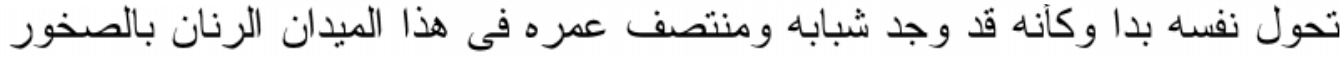

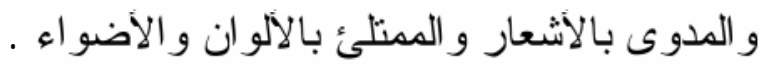

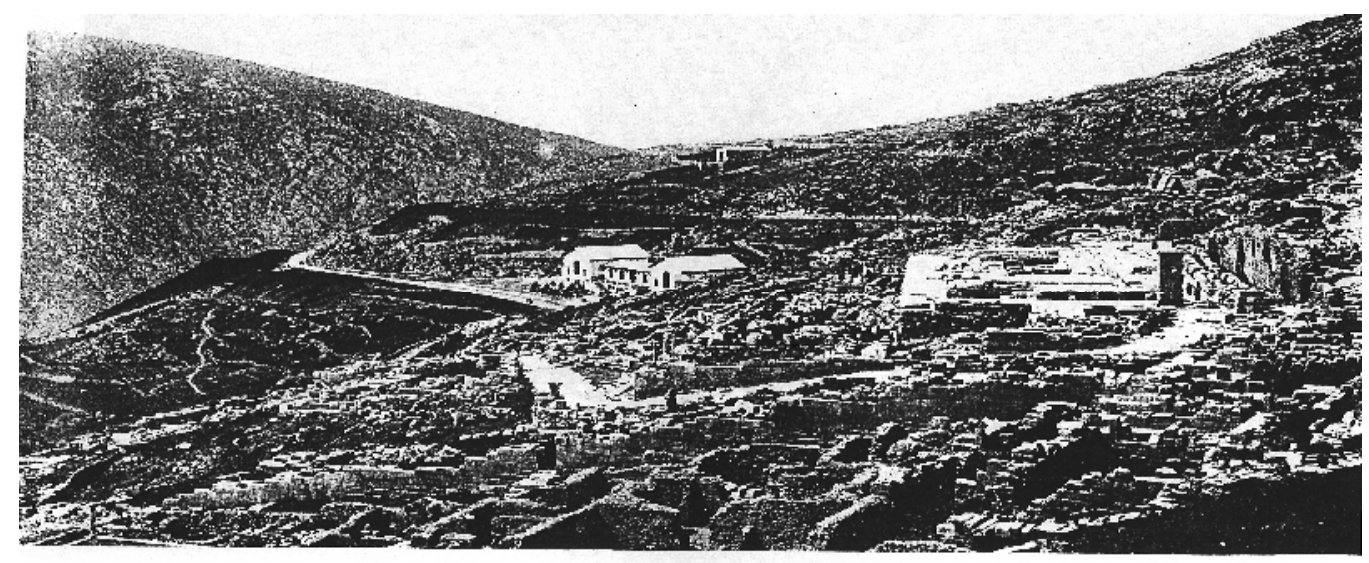


- ـ راسات في اثثار الوطن العريب

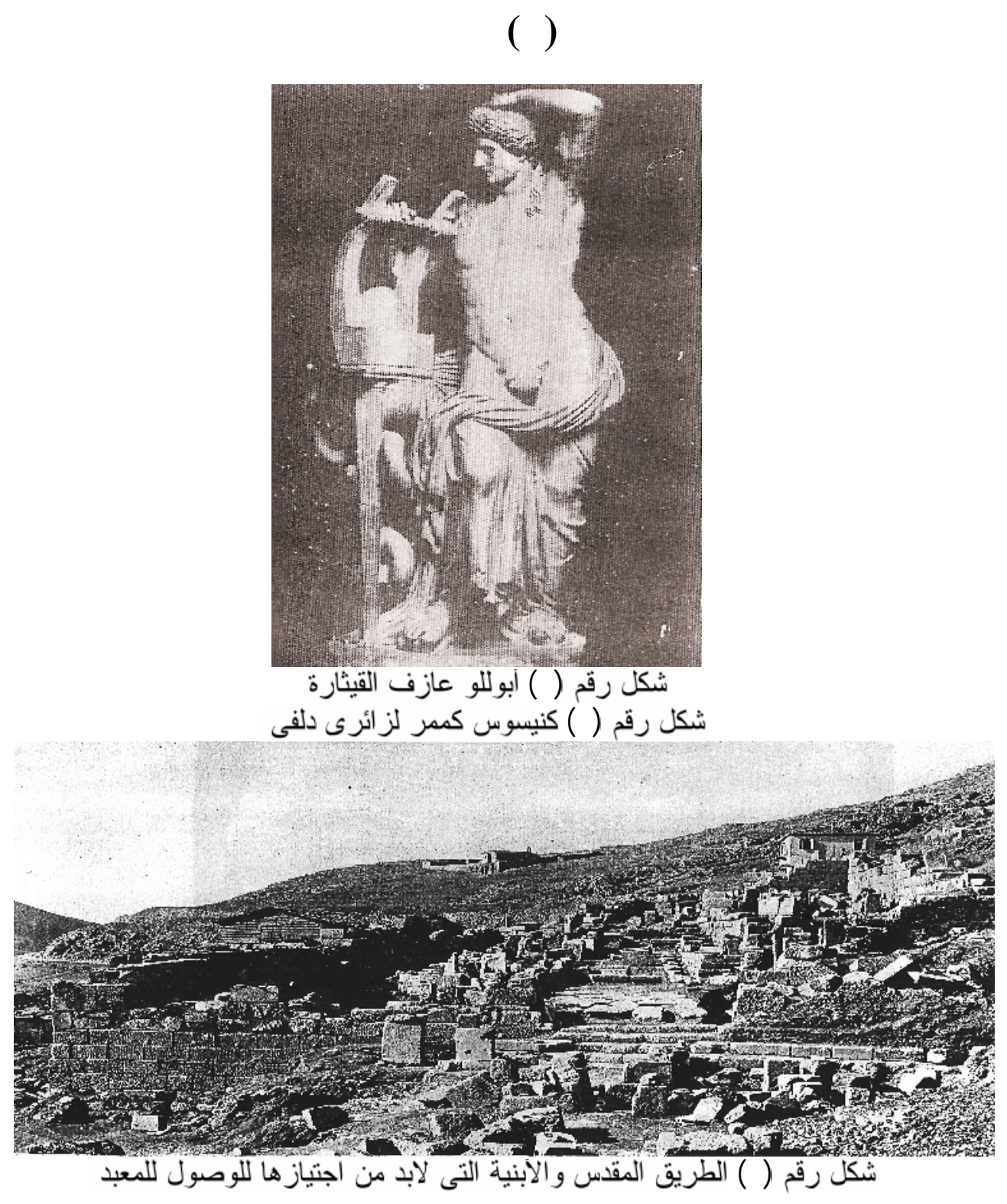

- 


\section{- ماسات في اثثار الوطن العربي -}

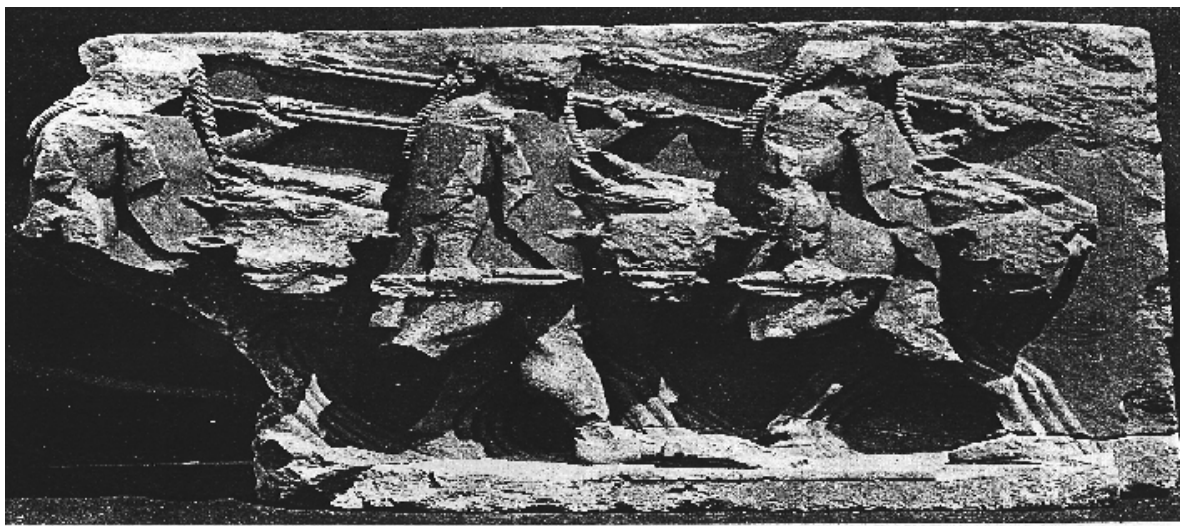

شكل رقم (0) ديوسوريس و ايداس ومعهم الابقار
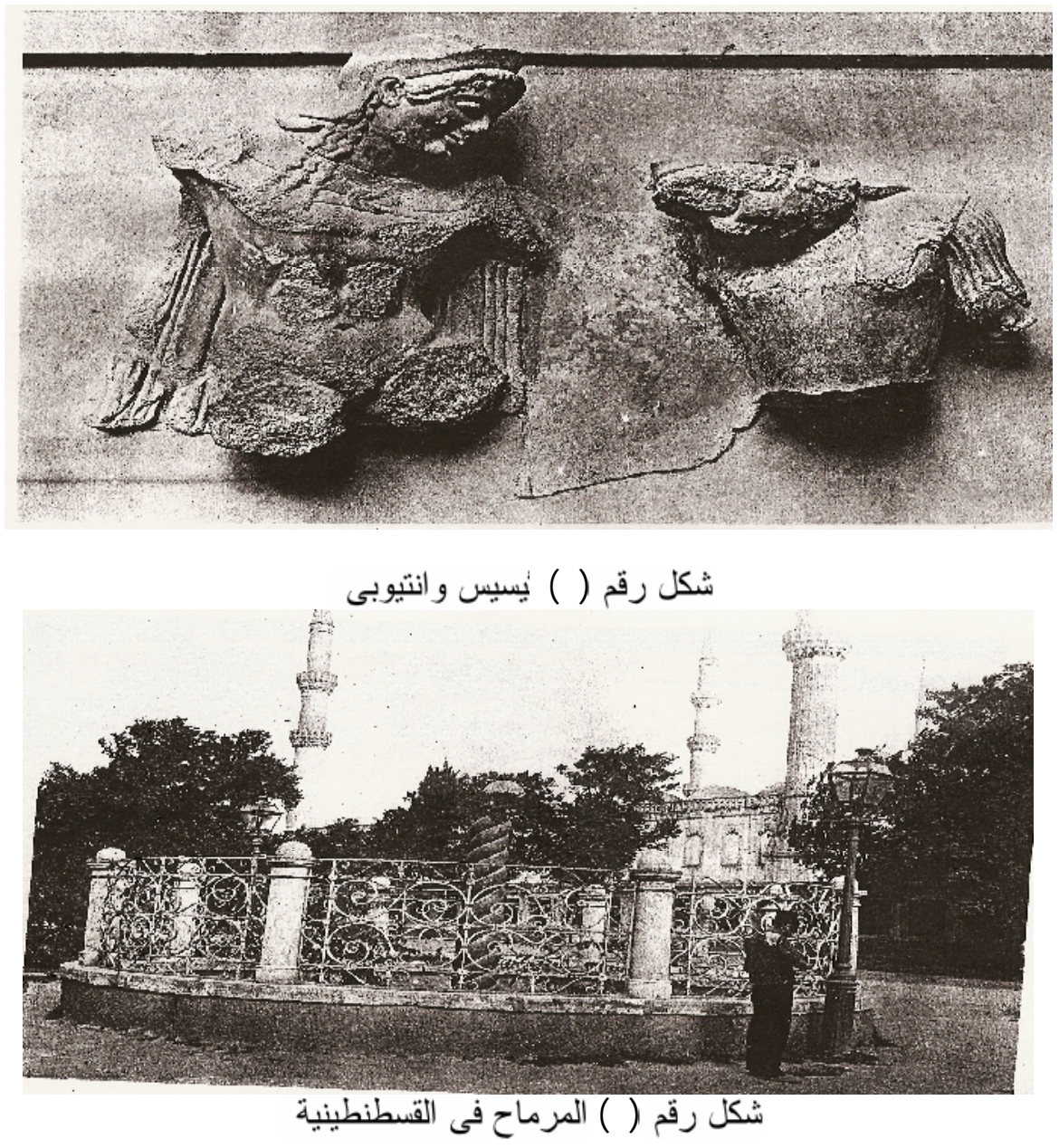

- rqv - 
- مراسات في اثار الوطن العربي -

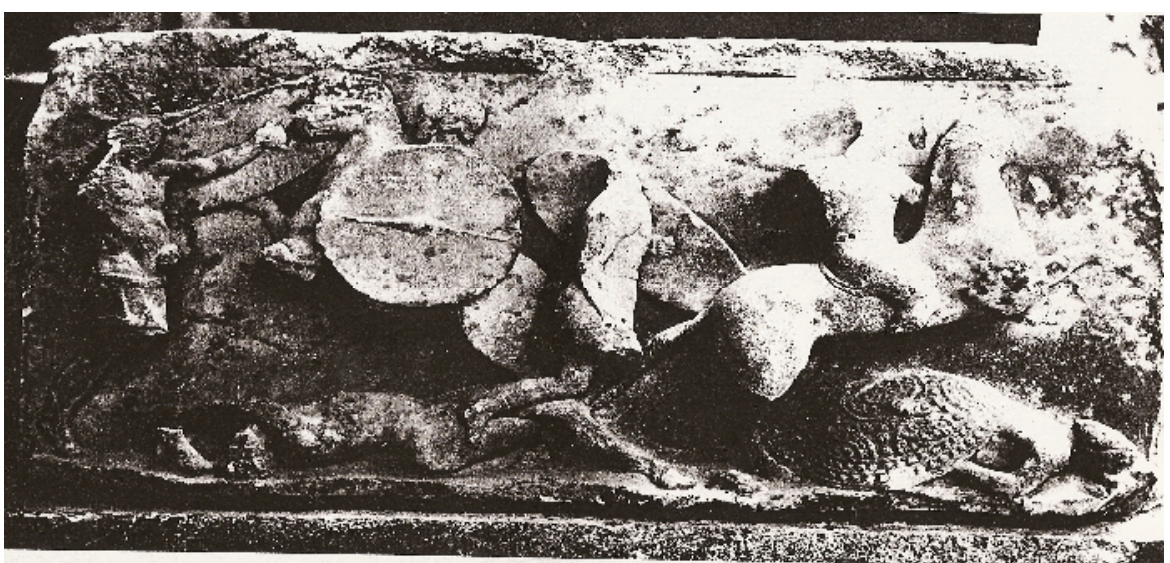

شكل رقم (^) منظر للنصب الخاص باول اميل Paul Emile

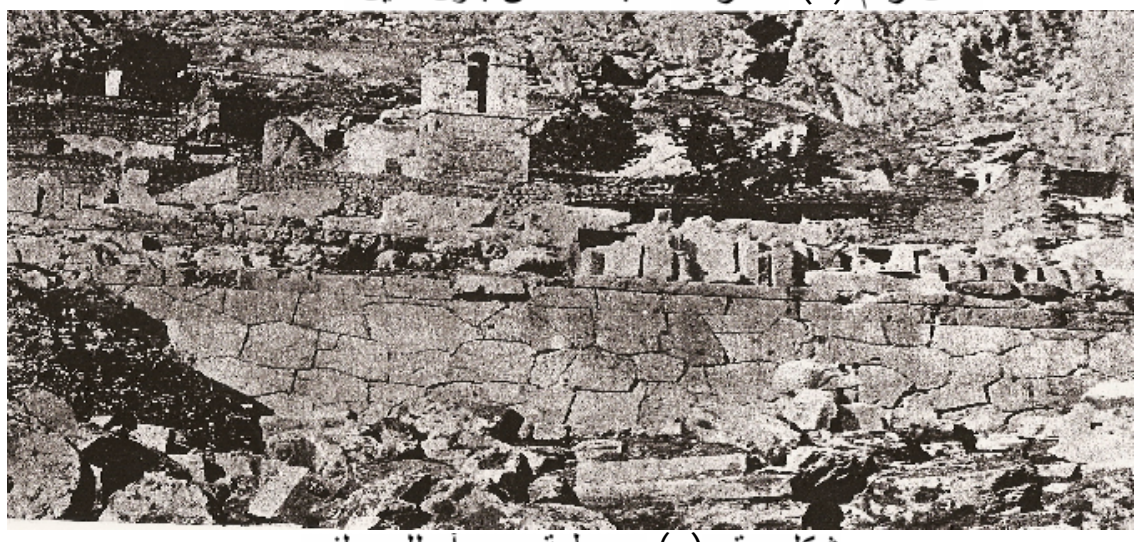

شكل رقم (9) مصطبة معبد ابوللو بدلفي

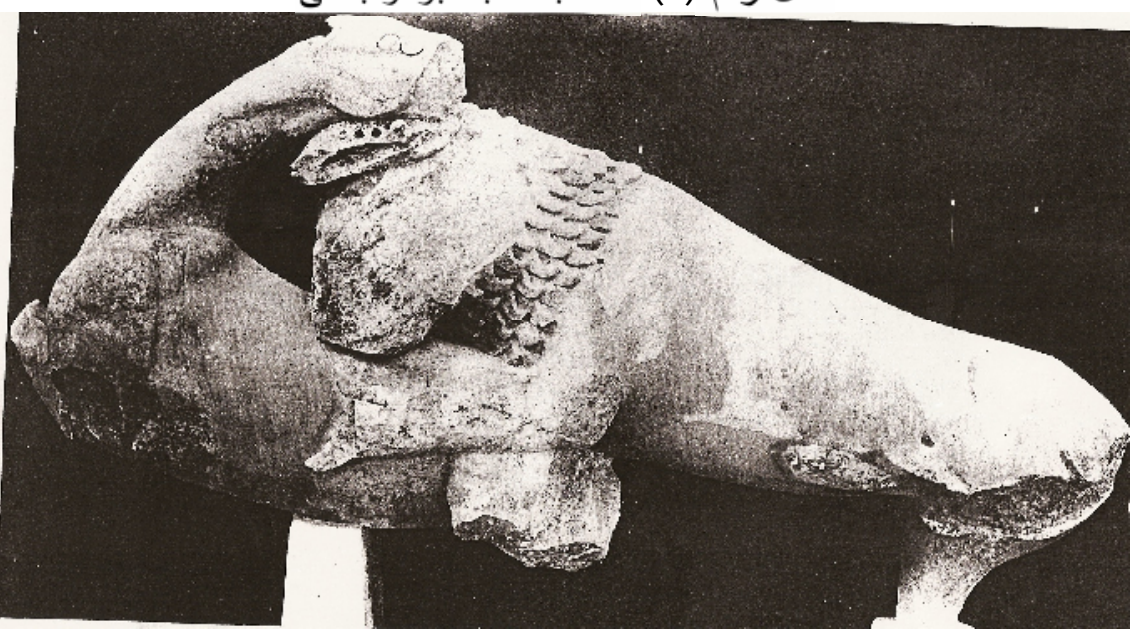

شكل رقم ( () أسد يلتهم ملاك مجنح 
- مراسات في اثثار الوطن العربي
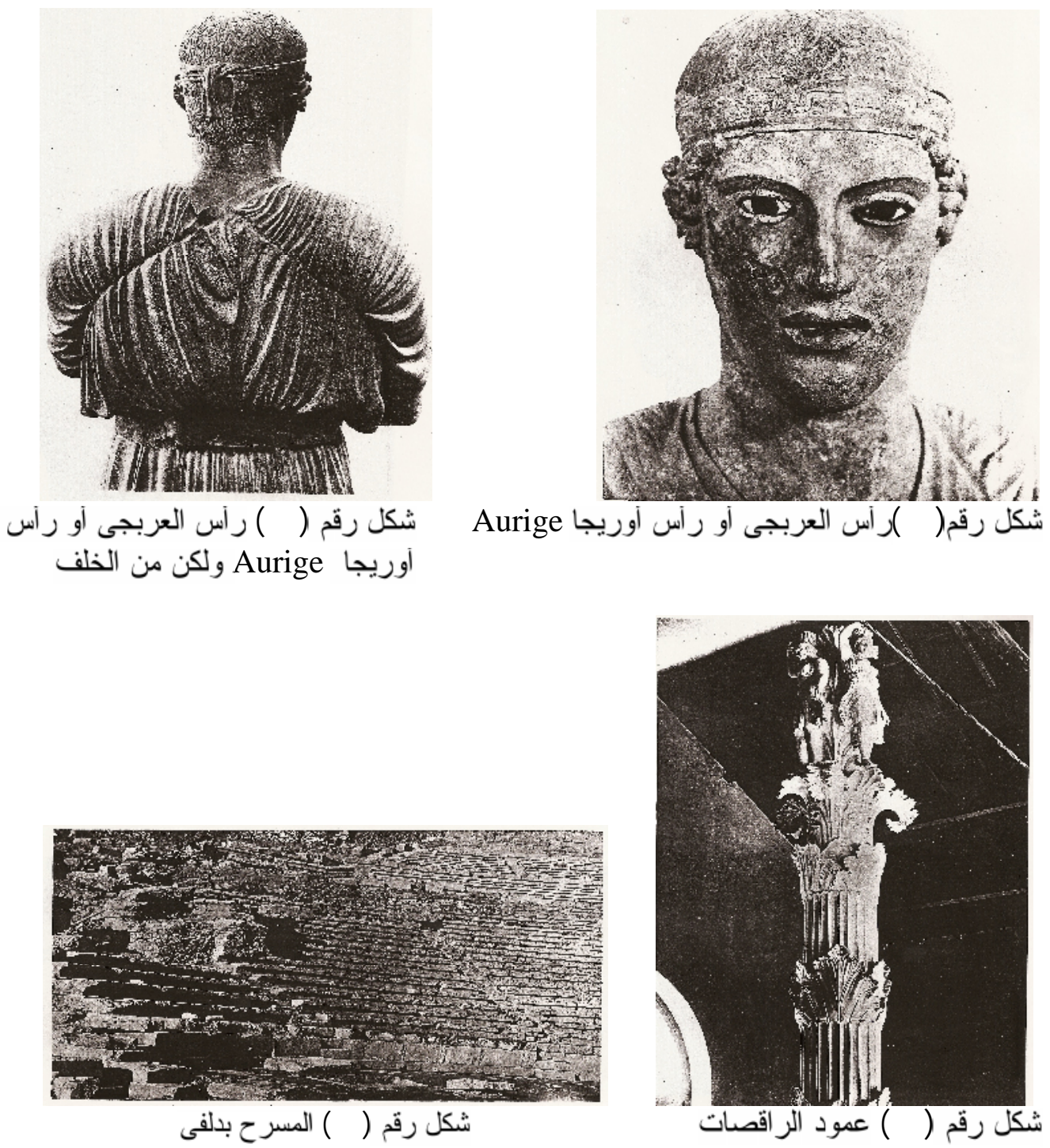
1 - مراسات في اثار الوطن العربي

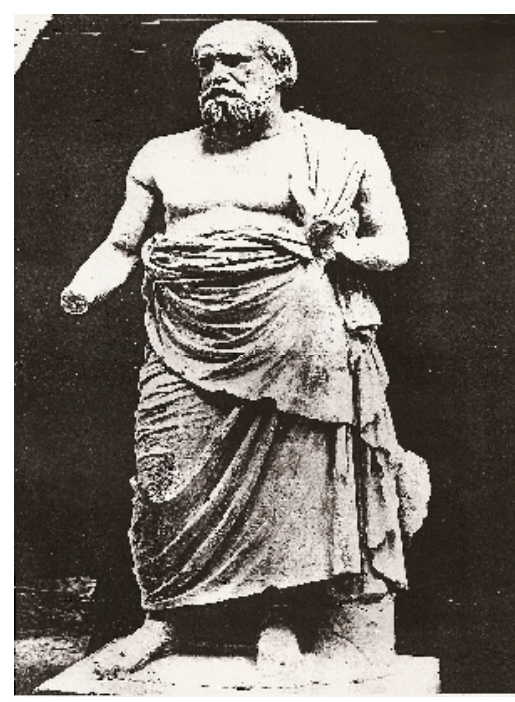

شكل (10) البطل الرياضى هاجياس Hauias شكل رقم (1 1) احد الفلاسفة وغير معروف اسمه

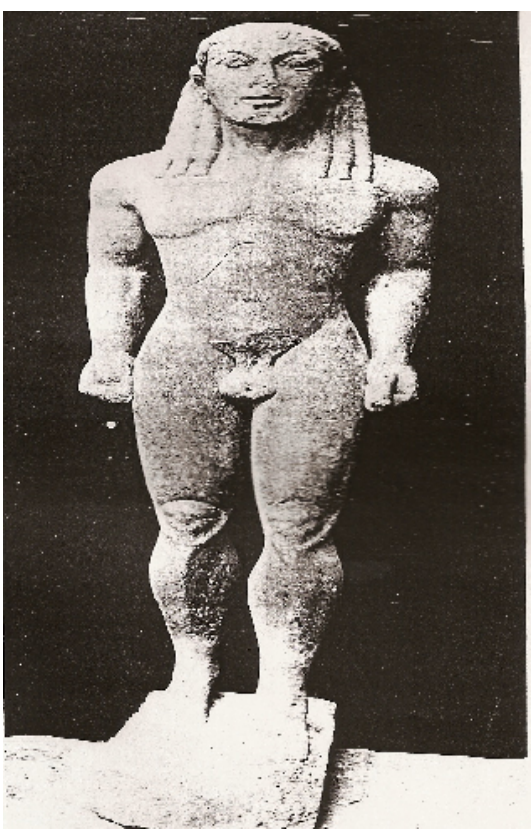

شكل رقم (IV) احد تماثيل آبوللو على الطريقة المصرية القديمة 


$$
\begin{aligned}
& \text { المراجع العرييه : } \\
& \text { 1) ثروت عكاشة ' الاغريق بين الاسطورة و الإبداع" ( الجزء الخامس عشر - الطبعة }
\end{aligned}
$$

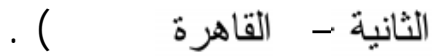

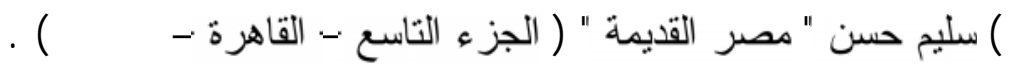

$$
\begin{aligned}
& \text { ") منى عبد الغنى حجاج 'محاضرات فى العارة الهيلينية '- ( الإسكندرية - } 1997 \text { ) }
\end{aligned}
$$

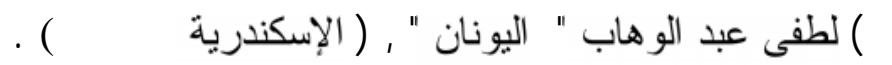

$$
\begin{aligned}
& \text { المصادر }
\end{aligned}
$$

1-Herodotu ,(Book I - IV)"translation by Godley",( Loeb ,class. libi). 2-Pausanias, " La Gréce translated by Périégèsis " X•

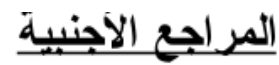

1-Bieber,M.,"The sculpture of the Hellenistic age"(New York,1955)

2-Bourguet, E. , " Les ruines de Delphes ", (Paris , 1914 ).

3- -------- , " Fouilles de Delphes Exécutees par ordre du Gouvernement Français et publiees, sous la direction de TH. HOMOLLE avec le concours des directeurs de L' Ecole francaise (en cours de publication .)

Decharme , P. " Mythologie de la Grèce antique ", Cinquieme edition , Paris ) .

5-Dillon, M. , "Girls and women in classical Greek Religion ", ( 2 ndedn Routledge ) (London and New York , 2000).

6- Dörpfeld,W., "Alt - Olympia",(Text and Tafelm ),(Berlim,1935).

7-Graindor , P. " Delphes " , ( Le Caire, 1930 ).

8-Guerber, A.H .," The story of The Greeks " ,( New York, 1886 ).

9- Hambidge , J. , " The Parthenon and other Greek temples, Their Dynamic symmetry ", ( New Haven, 1924 ).

10-Harris .H. A., "Greek Athletes and Athleties ",( London ,1964 ). 11-Kirk \& Bentley . " Ptolemaic coim . An introduction for collectore ", ( Toronto , 1995 ).

12- Mc Donald , W. A., " The Political Meeting places of the Greeks " , (Baltimore, 1943 ). 


\section{راسات في اثار الوطن العربي - 13}

13- Petrie , F. W. M ., " Temple of Apollo, Maucratis, details and column " , ( Restored ), ( Naukratis, 1886 ).

14-Picard, CH. , costemesselière , LA DE P. , " La Sculpture greeque a Delphes ", ( Paris , 1929 ).

15- Pomtow , H. article Delphoi dans la Real - Encyclopadie der classischen Altertums wissenschaft " , t. IV et suppl . IV

16 - Poulsem , F., " Delphi ", ( Londres, 1920 ) .

-

Robertson,S.D.,"Greek \& Roman Architectur",(Second Edition)

19- Widal - Naquet P. , " The Black Hunter forms of Thonght and forms of society in the ancient world " , ( London , 2000 ). 20Williamson, M. , " The Sacret and The Jeminine in Ancient Greece " , London and New York, 1998 ) . 21-Winter, F. E. , " Greek Fortifications, Routledge \& Kegan Paul ", ( London , 1971 ). 